\title{
AN EXPLORATION OF INDIANA AND OHIO FARMERS' \\ BELIEFS AND ATTITUDES \\ ABOUT FARMING METHODS AND NUTRITION
}

\author{
A THESIS \\ SUBMITTED TO THE GRADUATE SCHOOL \\ IN PARTIAL FULFILLMENT OF THE REQUIREMENTS \\ FOR THE DEGREE \\ MASTER OF SCIENCE \\ BY \\ LINDSAY SCHULTZ, RDN, LD \\ DR. DEANNA PUCCIARELLI, PHD - ADVISOR
}

BALL STATE UNIVERSITY

MUNCIE, IN

MAY 2020 


\begin{abstract}
THESIS: An Exploration of Indiana and Ohio Farmers' Beliefs and Attitudes about Farming Methods and Nutrition
\end{abstract}

STUDENT: Lindsay Schultz

DEGREE: Master of Science

COLLEGE: College of Health

DATE: $\quad$ May 2020

PAGES: $\quad 123$

According to the USDA, less than $1 \%$ of the farmland in Indiana and Ohio is organically managed. Organic farming has been shown to be beneficial to the environment by improving quality of the air, water and soil. Consumers associate organic foods with good health and nutrition and act on this belief by purchasing organic foods. The USDA reports that the demand for organic products continues to grow, with fruit and vegetable sales higher than other products. At the same time, the USDA acknowledges that the number of organic producers remains low, leading one to ask the question "why?". This qualitative research study aimed to explore what motivated farmers to use their specific farming method and to investigate farmers' thoughts in partnering with Registered Dietitians (RDNs) to improve the health of their communities by increasing fruit and vegetable consumption. Thirty to forty-five-minute face to face interviews were conducted with 24 farmers ( 8 conventional, 8 certified organic, and 8 non-certified organic). The results showed that economics, environment, government policies and health/nutrition were factors that influenced decisions the farmers made about their farming practices. The farmers in this study believed continuing education about farming practices was important to improve their businesses, and the quality of their products. The farmers were willing 
to collaborate with RDNs to promote their products and improve the health of the community. The farmers had ideas and suggestions for working with RDNs that focused on consumer education, accessibility, and community outreach. RDNs can explore opportunities and develop programs to work with farmers using the data from these research findings. If RDNs and farmers could work together to improve accessibility of fresh produce, educate the consumers about the importance of fresh produce, and reach out to communities in need, there could be increased consumption of fruits and vegetables. These partnerships between farmers and RDNs could lead to the prevention of chronic diseases and malnutrition in these communities as well as overall improved health outcomes. 


\section{ACKNOWLEDGEMENTS}

There are not enough ways to say thank you to my advisor, Dr. Deanna Pucciarelli, who has been by my side for the last year working on this project. She spent countless hours reading drafts and providing feedback to help make my thesis not just acceptable, but exceptional. She aided me in improving my writing skills and critical thinking skills which are essential in my career as a Registered Dietitian. Dr. Pucciarelli was available by email and phone and always made time to talk me through each step of this process.

I would like to thank my thesis committee members, Dr. Teresia Mbogori and Dr. Joshua Gruver. Their insights and recommendations throughout the process were essential to making my thesis come together. Dr. Christina Jones also took time out of her schedule to teach me how to use the NVivo software so I could analyze my data.

Dr. Carol Friesen played an instrumental role in helping me gather my thoughts and come up with the beginning ideas for my thesis project. Without her guidance through the Research Methods course, I would not have realized that I was drawn toward the idea of a qualitative study. Dr. Friesen has been a constant supporter since I came back to Ball State to begin my Master's degree in 2017. She has been my cheerleader from day one.

My mother, Cindy Ragon, and my brother, Eric Schultz, graciously agreed to be my research assistants and accompany me to each of the 24 interviews over the period of 6 months. In addition to being research assistants, my mom and brother were there to support me through the emotional part of the journey, comforting me in stressful moments and celebrating through each milestone. Thank you to Mom and Eric. You are the best family anyone could ask for.

Finally, I would like to thank all of the farmers who were willing to participate in the interviews for this project. They were very welcoming, inviting us into their homes and over for 
meals. The farmers were open and honest during the interviews and provided me with insight into the farming community. Meeting these farmers has inspired me to further explore how dietitians and farmers can work together. I am hopeful that this project will help guide me to other areas in my career as well as travel opportunities. To everyone who was involved in this project, you have made a difference in my schooling and my future, and I appreciate you more than you know. 


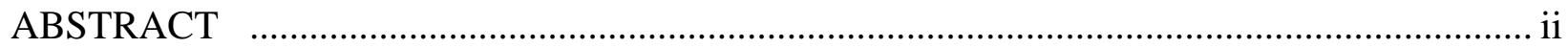

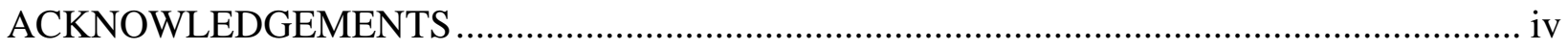

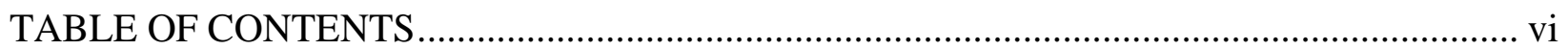

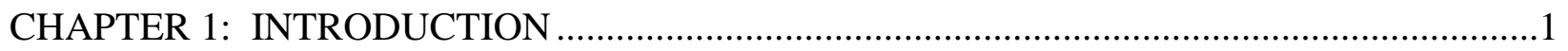

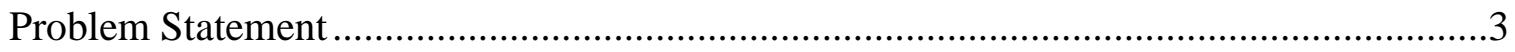

Purpose Statement.............................................................................................

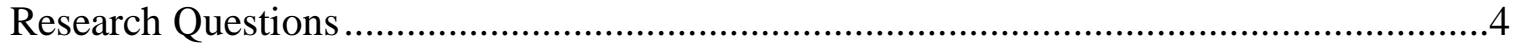

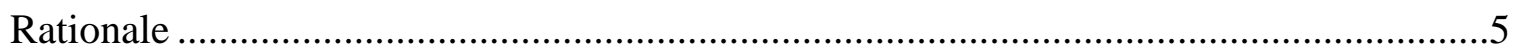

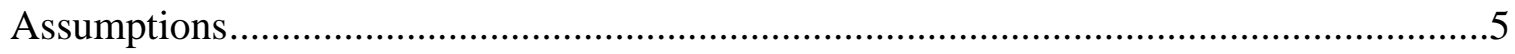

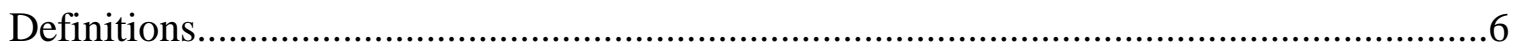

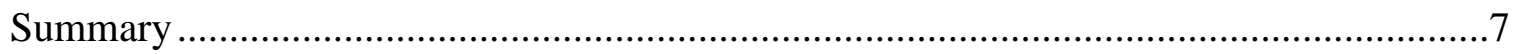

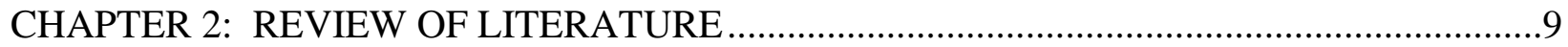

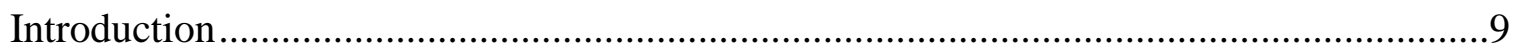

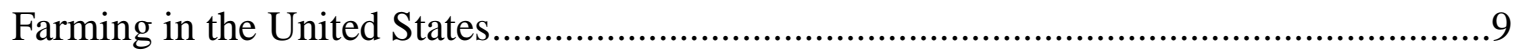

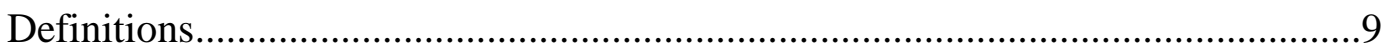

Farm Statistics in Indiana and Ohio............................................................11

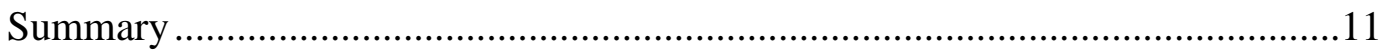

Farming Method Related to Health and Nutrient Content of Food ..................................12

Scientific Evidence ……..........................................................................12

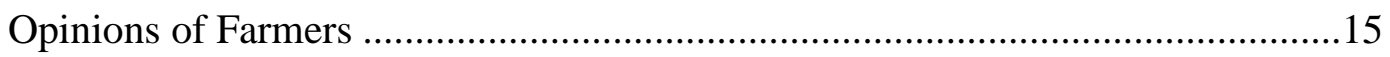

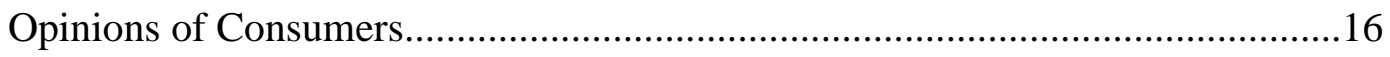

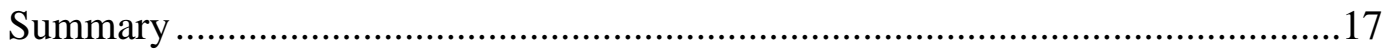


Farming Method Related to the Environment .............................................................18

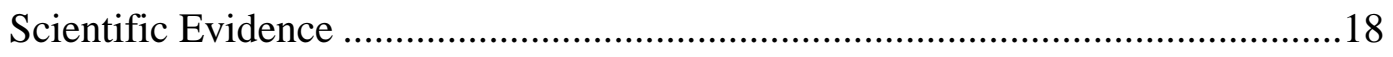

Opinions of Consumers ...............................................................................18

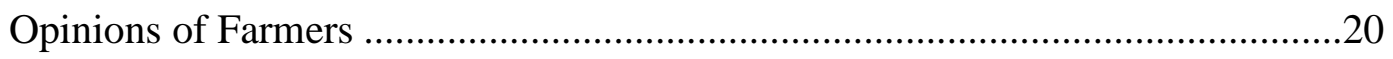

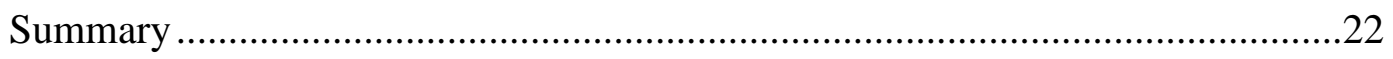

Review of Studies with Similar Theme and Design ......................................................22

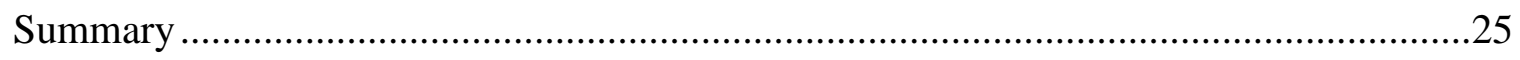

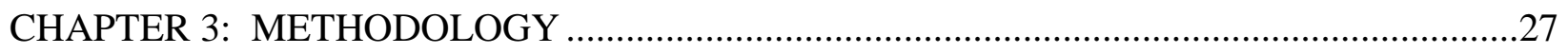

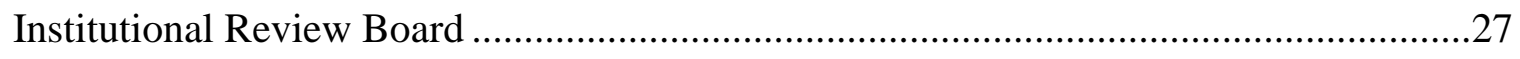

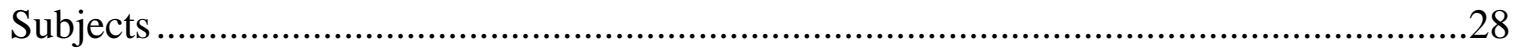

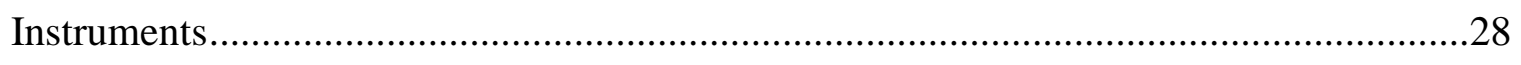

Letter of Informed Consent.....................................................................................29

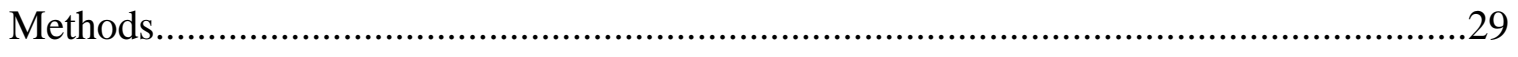

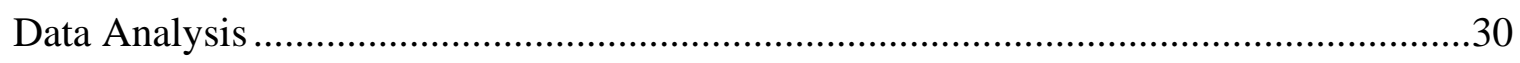

Summary

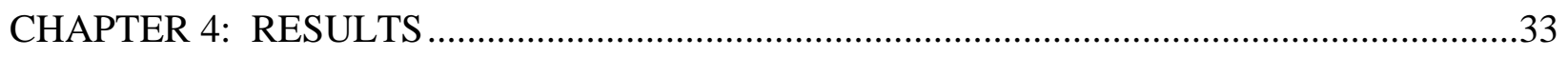

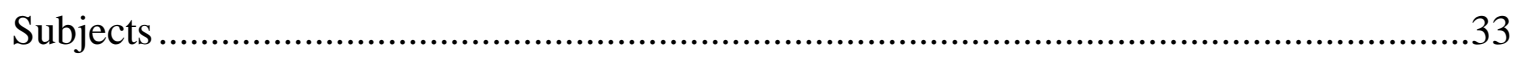

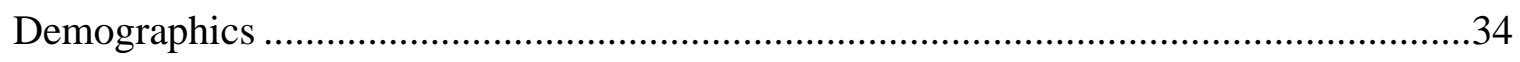

Main Themes and Subthemes ...................................................................................

RQ \#1: Factors Influencing Farming Methods ...............................................................38

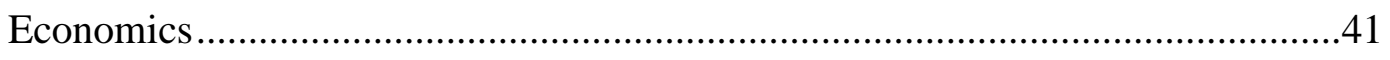

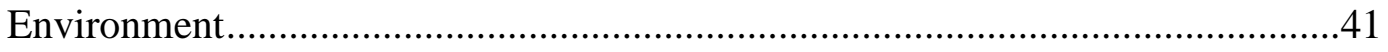




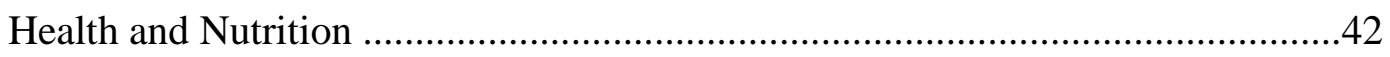

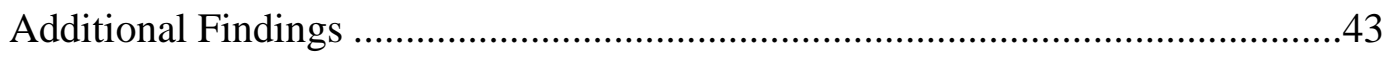

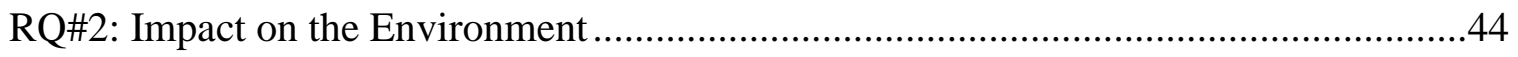

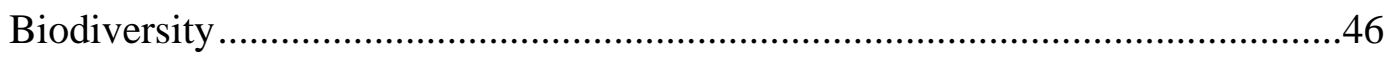

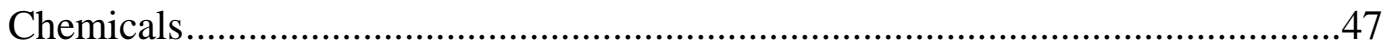

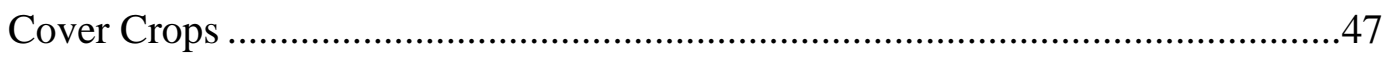

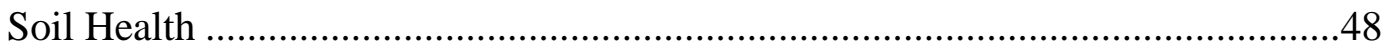

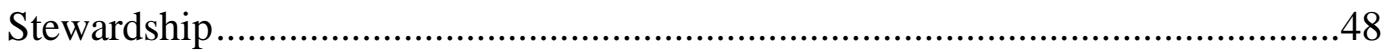

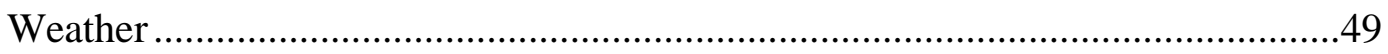

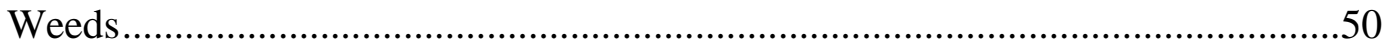

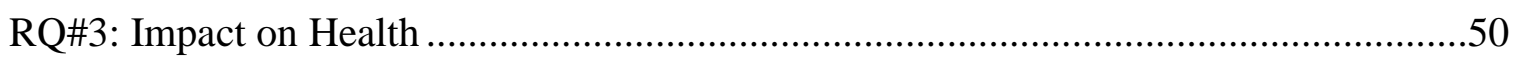

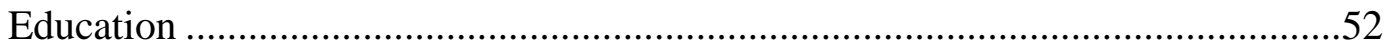

Fruit and Vegetable Consumption ...............................................................52

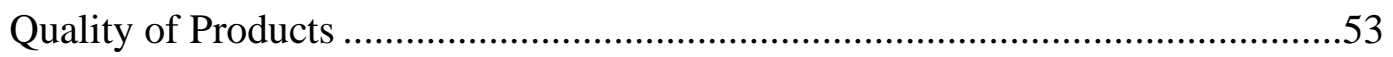

RQ\#4: Policies that Affect Farming …………………..........................................54

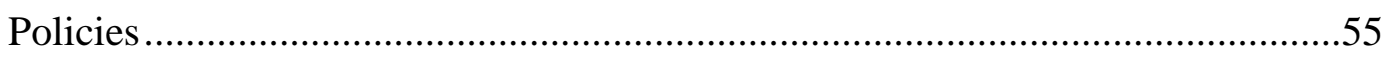

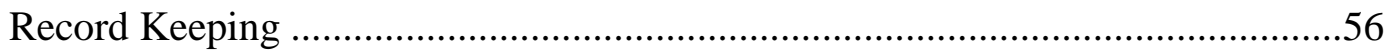

RQ\#5: Partnering with Registered Dietitian Nutritionists ............................................57

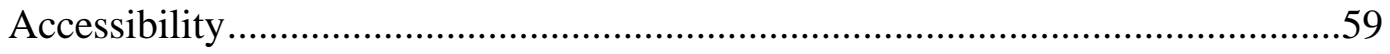

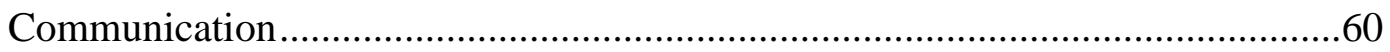

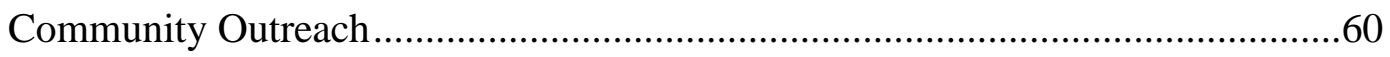




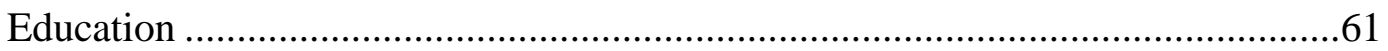

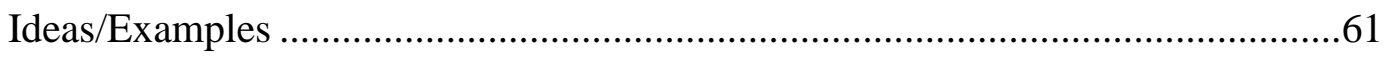

Additional Findings ………………………………............................................62

Conventional versus Organic Farming ..............................................................62

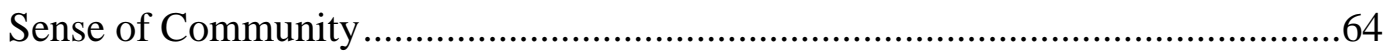

Continuing Education for Farmers..................................................................66

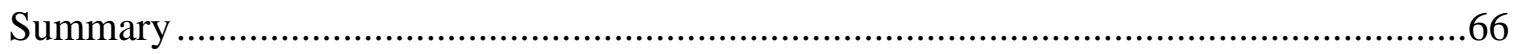

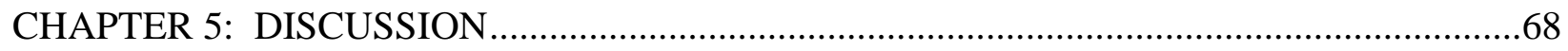

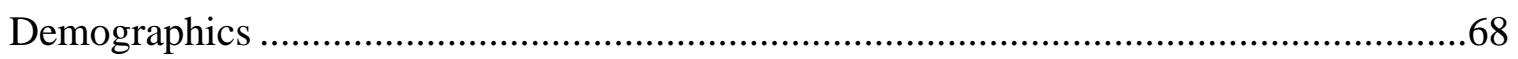

Comparison to National Averages ...................................................................68

Non-Certified Organic Farms ……………………...........................................

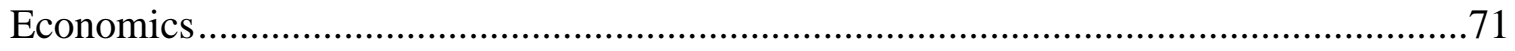

Consumer Demand for Organic Products .........................................................

Business versus Health/Nutrition and Environment .............................................72

Attitudes and Beliefs Related to Farming Methods ........................................................73

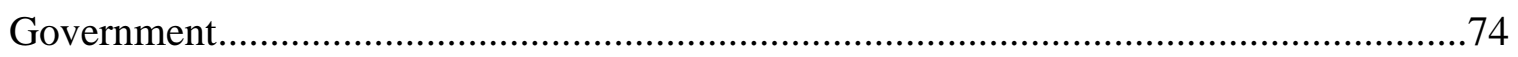

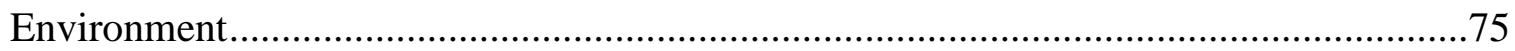

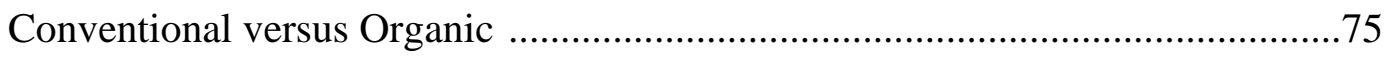

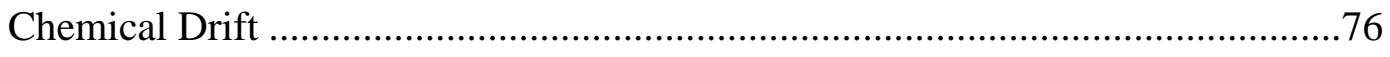

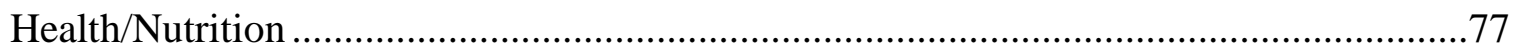

Working with Registered Dietitian Nutritionists ........................................................79

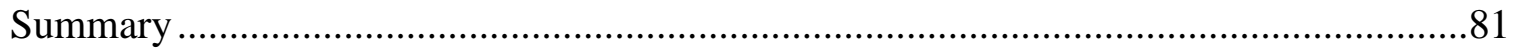




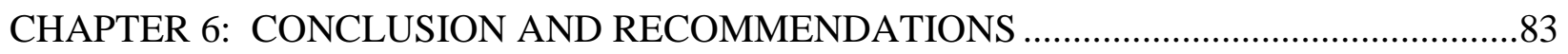

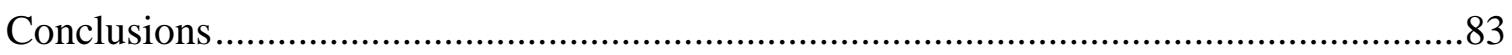

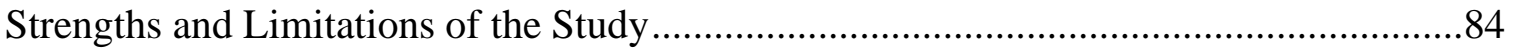

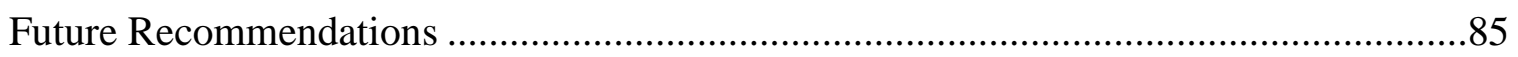

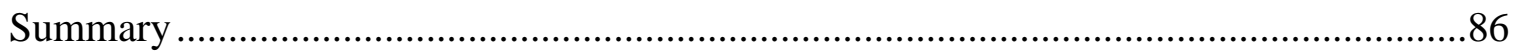

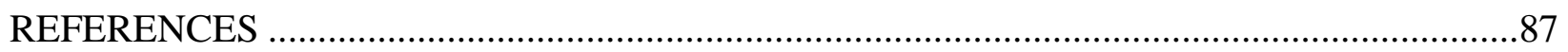




\section{LIST OF APPENDICES}

PAGE

Appendix A: Institutional Review Board Documents ..............................................92

A-1a: IRB Letter of Approval ................................................................93

A-1b: IRB Letter of Approval for Amendment ...............................................96

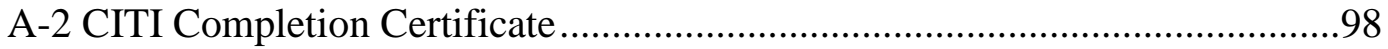

A-3: Individual Investigator Agreement form ...............................................99

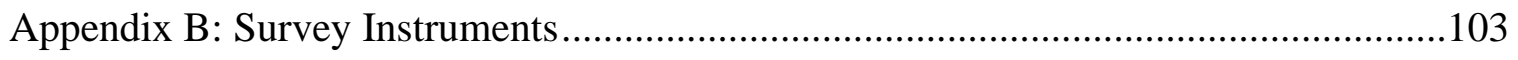

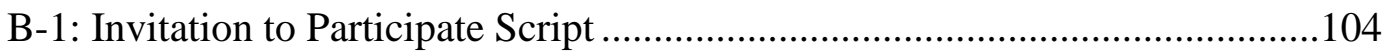

B-2: Interview Questions ................................................................... 105

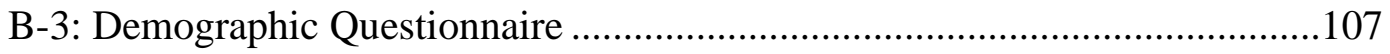

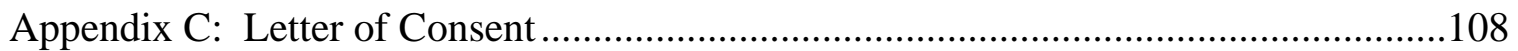

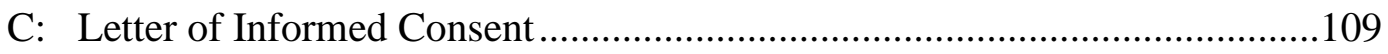




\section{LIST OF TABLES}

PAGE

Table $1 \quad$ Sample Demographics 35

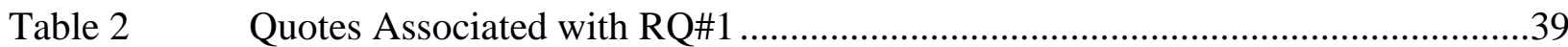

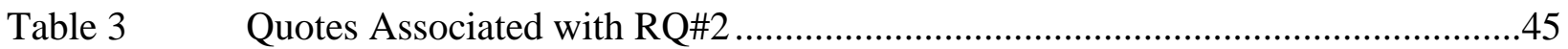

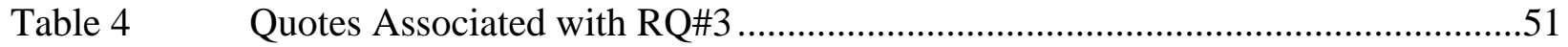

Table 5 Quotes Associated with RQ\#4 ...............................................................54

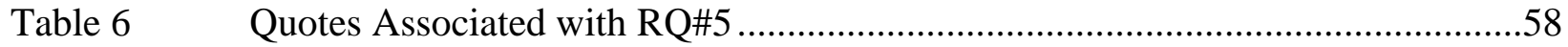

Table $7 \quad$ Demographics of Current Study versus National Average................................70 


\section{LIST OF FIGURES}

PAGE

Figure 1 Location Within a 100-mile Radius of Dayton, OH …………………..................34

Figure 2 Age Range and Years Operating Farm ..............................................................36

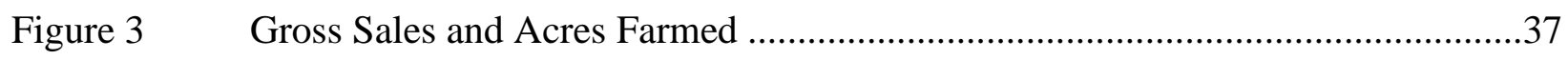

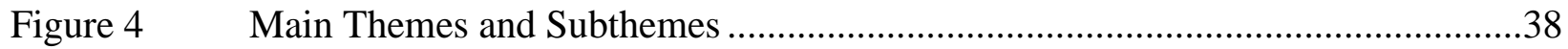




\section{CHAPTER 1}

\section{INTRODUCTION}

According to the 2017 United States Department of Agriculture (USDA) Agriculture Review, there are 56,800 farms in Indiana and 73,600 farms in Ohio (USDA Agriculture Review, 2017). Only 420 farms in Indiana (0.7\%), and 575 farms in Ohio (0.7\%), are certified organic (USDA Certified Organic Survey, 2016). Across the country, certified organic farms are more abundant, with the USDA Certified Organic Survey (2016) indicating there are 14,217 certified organic farms in the United States (USDA Certified Organic Survey, 2016). In California, for example, $3.5 \%(n=2,713$ of 77,100$)$ of the farms are certified organic. In New York, $3.0 \%(n=1,059$ of 35,500) of the farms are certified organic. In contrast, only $0.08 \%$ of the farms in Delaware ( $\mathrm{n}=2$ of 2,500) are certified organic (USDA Certified Organic Survey, 2016; USDA Agriculture Review, 2017). The disparity in the percent of farms that are certified organic leads one to ask what factors influence the percentages of certified organic farms in Indiana and Ohio.

Much research has been done to examine the difference in the nutrient content between organic and conventionally grown foods, with some studies showing no difference (Søltoft, Bysted, Madsen, Mark, Bügel, Nielsen, \& Knuthsen, 2011; Cardoso, Tomazini, Stringheta, Ribeiro, \& Pinheiro-Sant'Ana, 2011), and others showing that certain organic foods contain more vitamins and minerals (Nakamura, Fujita, Nakamura, \& Gotoh, 2007; Pérez-López, López- 
Nicolás, \& Carbonell-Barrachina, 2006; Amodio, Colelli, Hasey, \& Kader, 2007). Many researchers (Smith-Spangler, Brandeau, Hunter, Bavinger, Pearson, Eschbach, Sundaram, Liu, Schirmer, Stave, Olkin \& Bravata, 2012; Mie, Andersen, Gunnarsson, Kahl, Kesse-Guyot, Rembiałkowska, Qualglio \& Grandjean, 2017; Johansson, Hussain, Kuktaite, Andersson, \& Olsson, 2014) concluded that there is not enough strong and consistent evidence to say that organic foods are more nutritionally healthful than their conventionally produced counterparts. Interestingly, despite the lack of evidence, research shows that consumers clearly associate organic foods with health and good nutrition (Dahm, Samonte, \& Shows, 2009; Michaelidou \&Hassan, 2008).

While there may not be a strong evident nutritional difference between organic and conventionally grown foods, the environmental aspects of farming are important to consider (The International Federation of Organic Agriculture Movements (IFOAM), 2018). The IFOAM report suggests that organic farming can be beneficial to the environment in many ways, including improving the air, water and soil. Organic agriculture uses techniques such as crop rotation, inter-cropping, cover crops and organic fertilizers, all of which help organic agriculture be sustainable and environmentally friendly (IFOAM Organic Basics, 2018). Research conducted with farmers shows that organic farmers have a higher appreciation for the environment than conventional farmers (Darekar \& Naik, 2017; Thompson, Reimer, \& Prokopy, 2015; Welsh \& Rivers, 2011).

Consumers associate organic foods with health and nutrition (Dahm, Samonte, \& Shows, 2009; Michaelidou \& Hassan, 2008). As consumers look for healthy food options for themselves and their families, many turn to organic foods, despite the higher cost (Meyer, 2017).

Consumers who believe organic foods are more healthful than foods grown conventionally often 
act upon this belief and purchase organic foods (Dahm, Samonte, \& Shows, 2009; Çabuk, Tanrikulu, \& Gelibolu, 2014). According to the USDA, consumer demand for organic products continues to grow, with fruits and vegetables being the top selling organic products (USDA Economic Research Service, 2017).

The USDA acknowledges that the number of organic producers remains low, which they contribute to low crop yields and challenges for weed control, as well as a possible lack of information about cost and return (USDA Economic Research Service, 2017). If farmers could reap a higher profit and meet the demands of consumers by using organic farming techniques, one must ask why the majority of farmers in Indiana and Ohio choose conventional farming methods over organic farming methods. Exploring the reasons for their choices and their attitudes toward farming methods could provide insight into the decisions that Indiana and Ohio farmers make regarding farming methods and food production. These farmers could make changes that may give consumers the perceived healthful options they demand while potentially positively impacting the environment.

\section{Problem Statement}

The majority of the farms in Indiana and Ohio chose to use conventional agricultural methods, while less than $1 \%$ of the farms are certified organic (USDA Certified Organic Survey, 2016; USDA Agriculture Review, 2017). Although there is limited evidence to indicate organic foods are healthier than conventionally grown foods (Smith-Spangler et al, 2012; Mie et al, 2017; Johansson et al, 2014), consumer-based research clearly shows that consumers associate organic foods with health and good nutrition (Dahm, Samonte, \& Shows, 2009; Michaelidou \&Hassan, 2008; Çabuk, Tanrikulu, \& Gelibolu, 2014). Despite the higher costs, health- 
conscious consumers demand organic foods at an increasingly high rate (Meyer, 2017; USDA Economic Research Service, 2017). In addition, organic farming has been shown to be beneficial to the environment by improving air, water and soil (IFOAM Organic Basics, 2018). Understanding farmers' attitudes toward organic farming and the factors that cause them to select their current method of farming will provide insight into why Ohio and Indiana farmers have less often chosen organic food production, which could give consumers the perceived healthful options they demand while also having a positive impact on the environment.

\section{Purpose Statement}

The purpose of this qualitative study was to explore the attitudes and factors that motivated farmers from Indiana and Ohio to operate either a certified organic, a non-certified organic, or a conventional farm, and to explore the interest of farmers in partnering with Registered Dietitian Nutritionists (RDNs) in educating consumers about the health benefits of eating fruit and vegetables to increase daily consumption.

\section{Research Questions}

The following research questions were explored in this study:

RQ\#1: What factors influenced farmers to operate a certified organic, a non-certified organic, or a conventional farm?

RQ\#2: How do the farmers view the impact they have on the environment?

RQ\#3: How do the farmers view the impact they have on the health and wellbeing of their consumers? 
RQ\#4 Are there farming related polices in Indiana, Ohio and nationally that support or create a barrier to farming?

RQ\#5 Have farmers considered partnering with a Registered Dietitian Nutritionist to increase consumer awareness of health benefits of their products?

\section{Rationale}

The responses from the farmers in this qualitative study will provide insight into factors that motivate or inhibit farmers to run a certain type of farm. There are rules and regulations farmers must follow to operate a certified organic program. The discussion with farmers could convey determinants to their decisions to run an organic versus a conventional farm. The impact on the environment and health/nutrition outcomes of their consumers could be factors that influence farming decisions. Information obtained from this study could be used to identify farmers' attitudes and beliefs. Promotional materials to increase organic farming in Indiana and Ohio might promote, limited research suggests, consumers' nutritional health and wellness and help improve the environment. Farmers may show an interest in working with RDNs to help inform consumers about the health and nutrition of their products.

\section{Assumptions}

The researcher made the following assumptions in the implementation of the study and in the interpretation of the data:

1. The participants understood the meaning of the questions asked.

2. The participants provided honest and complete answers to the questions. 


\section{Definitions}

For the purpose of this study, the following definitions will be used:

1. Conventional Agriculture - a farming system which includes the use of synthetic chemical fertilizers, pesticides, herbicides and genetically modified organisms.

2. Organic Agriculture - a farming system that does not use synthetic fertilizers or pesticides and supports ecological balance and cycling of resources.

3. Certified Organic - Products that are certified by the USDA. The product must have been produced without synthetic chemicals and must be produced on land which prohibits synthetic chemicals for more than 3 years, and does not use genetic modification.

4. Non-certified Organic farm- a farm that grows products without any pesticides or herbicides, but does not have an official USDA certification. These farms cannot use the word "organic" when marketing their products. They usually use terms like "natural" or "chemical free".

5. Sustainability - Avoidance of the depletion of natural resources in order to maintain an ecological balance.

6. United States Department of Agriculture (USDA) - The U.S. federal department responsible for developing and executing federal laws related to farming, forestry, and food.

7. International Federation of Organic Agriculture Movements (IFOAM) - The worldwide organization for the organic agriculture movement, which represents close to 800 affiliates in 117 countries. 
8. Crop rotation - The practice of growing a series of different types of crops in the same area in sequenced seasons. It helps to reduce soil erosion and increases soil fertility and crop yield.

9. Inter-cropping - The growing of two or more crops in proximity to produce a greater yield on a given piece of land by making use of resources.

10. Cover crops - A crop planted mainly to manage soil erosion, soil fertility, soil quality, water, weeds, pests, diseases, and biodiversity.

11. Organic fertilizers - Fertilizers derived from animal or vegetable matter.

12. Full Time Job: The money obtained from the farm is the farmer's sole source of income.

13. Secondary Job: The farmer receives an income from another source besides the farm.

14. Ohio Ecological Food and Farm Association (OEFFA): Organization that cultivates a future in which sustainable and organic farmers thrive, local food nourishes communities, and agricultural practices protect and enhance the environment. OEFFA certification currently accepts new applications from operations in Ohio, Illinois, Indiana, Iowa, Kentucky, Michigan, Missouri, New York, Pennsylvania, Virginia, West Virginia, and Wisconsin.

\section{Summary}

The method of farming used can have an impact on the environment and, potentially, on the health and nutrition of consumers. Indiana and Ohio have a low percentage of organic farms while most of the farms are run using conventional agriculture. By exploring farmers' attitudes and beliefs of the different farming methods, information can be gathered as to what motivates them to choose their method of farming. The information gathered from this qualitative research study could be used for further research topics in this area. There could be valuable insight 
gained, which would help guide RDNs to work with farmers in building programs to increase organic farming and fruit and vegetable consumption in these two midwestern states. This could lead to, among other potential benefits, a healthier community and environment. 


\section{CHAPTER 2}

\section{REVIEW OF LITERATURE}

The purpose of this qualitative study was to explore the attitudes and factors that motivated farmers from Indiana and Ohio to operate either a certified organic, a non-certified organic, or a conventional farm, and to explore the interest of farmers in partnering with Registered Dietitian Nutritionists (RDNs) in educating consumers about the health benefits of eating fruit and vegetables to increase daily consumption. This chapter will present a review of the literature that: 1) describes farming in the United States (specifically in Indiana and Ohio); 2) describes the impact of farming methods on human health and the nutrient content of food; 3 ) describes how the farming methods impact the environment, and 4) reviews studies similar to the design of the current study.

\section{Farming in the United States}

\section{$\underline{\text { Definitions }}$}

Conventional farming is defined by the United States Department of Agriculture (USDA) as farming that uses seeds, which have been genetically altered using a variety of breeding methods and are not certified as organic (USDA Conventional Farming, 2015). A variety of breeding methods have been used to help with faster growth, higher yields, pest control, disease resistance and better produce (USDA Conventional Farming, 2015). Chemicals such as 
pesticides and herbicides can be used on these conventional crops as well (USDA Conventional Farming, 2015).

The United States Environmental Protection Agency (EPA) defines "organically grown" as food, which is grown and processed with no synthetic fertilizers or pesticides (EPA Organic Farming, 2018). The USDA defines organic agriculture as a set of cultural, biological and mechanical practices that support cycling of resources, promote ecological balance and conserve biodiversity (USDA Introduction to Organic Practices, 2015). Some examples of these practices include: maintaining or enhancing water and soil quality, conserving wetlands and wildlife, and avoiding synthetic fertilizers, sewage sludge, and genetic engineering. The USDA requires that organic farmers use natural processes and materials in their systems to help with soil nutrition, pest and weed management, and the environment (USDA Introduction to Organic Practices, 2015). In order to sell a product with the official label of "USDA organic", the farmers must be certified (USDA Organic Labeling, 2018). The Organic Foods and Production Act of 1990 states that in order to be labeled as "organic", the product must have been produced without synthetic chemicals and produced on land which has prohibited synthetic chemicals for more than 3 years (USDA Organic Food Production Act of 1990, 2005). According to the EPA, organic agriculture began in the United States in the 1940s (EPA Organic Farming, 2018). As this type of agriculture has grown, it has become evident that standards, set by the National Organic Program, are needed for organic products (EPA Organic Farming, 2018).

Farmers who do not have a USDA certification but still want to sell organic produce would be called non-certified organic. Without obtaining a certification, they cannot use the term "organic" when marketing their produce. They would simply sell their products as "natural" or "chemical free" or "pesticide free". These farmers do not have any rules or regulations that 
monitor their farming practices. These are usually smaller local farmers selling at farmers markets.

$\underline{\text { Farm Statistics in Indiana and Ohio }}$

Indiana and Ohio are two states that have a large amount of farmland. According to the 2017 USDA Agriculture Review from Quick Stats, Indiana has a total of 56,800 farms and Ohio has a total of 73,600 farms (USDA Agriculture Review, 2017). According to the 2016 Certified Organic Survey from the USDA National Agricultural Statistics Service, there are 14,217 certified organic farms in the United States (USDA Certified Organic Survey, 2016). California, for example, has 2,713 certified organic farms out of 77,100 total farms (3.5\%). In contrast, there are only 420 and 575 organic farms in Indiana and Ohio, respectively; therefore only $0.74 \%$ of the farms in Indiana and $0.78 \%$ of the farms in Ohio are certified organic. (USDA Certified Organic Survey, 2016; USDA Agriculture Review, 2017). With less than $1 \%$ of the farms in these states certified organic, one must ask what factors influence farmers in these states to choose conventional farming methods or follow organic practices but not obtain certification.

\section{Summary}

Conventional farming is a type of farming, which uses pesticides, herbicides and genetically modified seeds to help with faster growth, higher yields, pest control, disease resistance and larger seeds or sweeter fruit (USDA Conventional Farming, 2015). Organic farming, on the other hand, does not use synthetic pesticides or fertilizers. Organic farming can be beneficial for the environment by improving air, water and soil quality (USDA Introduction to Organic Practices, 2015), while decreasing consumer ingestion of chemicals, often petroleum- 
based. Indiana and Ohio have some organic farms, but less than $1 \%$ of the farms in these states are certified organic (USDA Certified Organic Survey, 2016; USDA Agriculture Review, 2017). Although organic farming is becoming more popular, the statistics indicate the majority of farms in Ohio and Indiana use conventional methods.

\section{Farming Method Related to Health and Nutrient Content of Food}

\section{$\underline{\text { Scientific evidence }}$}

In a comprehensive review of the literature, Smith-Spangler et al. (2012) reviewed 17 studies on humans and 223 studies of nutrient and contaminant levels in organic and conventionally produced food. In general, the researchers did not find consistent or overwhelming evidence that organic foods were more nutritious than conventionally produced foods. Studies examined vitamin and nutrient levels and contaminant levels. They did find that conventional produce had a $30 \%$ higher risk for pesticide contamination compared to organic produce.

Few studies have been found in the literature that have compared the long-term health of people who consumed diets consisting primarily of organic food compared to those who consumed primarily conventionally grown foods. One study examined the amount of pesticides in the urine of children aged 3-11 years when they were switched from a standard diet to an organic diet (Lu, Barr, Pearson \& Waller, 2008). Results indicated the amount of pesticides in the urine decreased when subjects ate an organic diet. The researchers concluded that dietary sources of pesticides are a significant source of pesticide exposure to children.

Nakamura et al. (2007) conducted a study to determine the nutrient content of soybeans that were harvested from organic and conventional farming areas. Results indicated the protein 
content was significantly $(\mathrm{p}<0.001)$ higher in organic soybeans than conventionally farmed soybeans. Calcium and phosphorus were higher in organic soybeans by $50-100 \mathrm{mg}$ and potassium was higher in organic soybeans by over $4000 \mathrm{mg}$. These researchers concluded that the type of farming used made a difference in the composition of some products, especially during storage time.

Pérez-López et al. (2007) examined the mineral content of mandarin oranges that were grown organically versus conventionally grown. The researchers looked at many minerals, including iron, copper, manganese, zinc, calcium, magnesium, potassium and sodium, in the juice from organic and conventionally produced mandarins. The results indicated that organic mandarins had a significantly $(\mathrm{p}<0.001)$ higher concentrations of all of the previously mentioned minerals.

Mie et al. (2017) provided a comprehensive review of studies that compared the nutrient content of organic versus conventionally produced food. Many of the points discussed were consistent with Smith-Spangler et al. (2012). Overall, although organic foods were found to have a lower risk of pesticide exposure, there were minimal differences in the nutrient composition between organic and conventionally produced foods. These researchers reported there was insufficient evidence to link organic food consumption to direct health benefits, and suggested long-term studies to compare health of people who consume organic versus conventional foods need to be conducted.

Bradbury et al. (2014) conducted a study which examined the hypothesis that eating organic food may reduce the risk of soft tissue sarcoma, breast cancer, non-Hodgkin lymphoma, and other common cancers. They studied 623,080 middle-aged women living in the UK. The women reported their consumption of organic foods, and were followed for 9.3 years to monitor 
incidence of cancers. The researchers found little or no decrease in incidence of cancer when subjects consumed organic food. The exception was non-Hodgkin lymphoma, where they found a $21 \%$ lower risk of this specific disease in women who usually or always consumed organic foods.

Søltoft et al. (2011) examined the effect of organic vs conventional farming on carrot roots. They found no significant differences in the content of carotenoids in the organic carrots versus the conventionally farmed carrots. These researchers concluded that the type of farming method used did not affect the amount of carotenoids in carrot roots.

Johansson, et al. (2014) reviewed the literature on organic versus conventionally produced food. Like other researchers, these researchers found no clear benefits in nutrient content between the two groups. They reported that there are many animal and in vitro studies, which show potential benefits, but the research on humans is very limited. They found that pesticide residues are less in organic foods than conventionally produced foods.

Amodio et al. (2007) examined the nutrient content of organic versus conventionally grown kiwifruits. These researchers examined the physical condition of the fruits and the mineral contents. The researchers found that organic kiwifruits had a significantly $(\mathrm{p}<0.05)$ higher concentration of minerals and a higher level of ascorbic acid and phenol content, which causes organic kiwifruits to have a higher antioxidant activity than conventionally grown kiwifruits.

Cardoso, Tomazini, Stringheta, Ribeiro, \& Pinheiro-Sant'Ana, (2011) examined the amount of vitamin $\mathrm{C}$ and carotenoids in three different organic and conventionally grown fruits in Brazil. Persimmons, acerolas, and strawberries were examined for vitamin $\mathrm{C}$ and carotenoid contents. The study indicated mixed results. For example, organic acerolas had significantly 
$(\mathrm{p}<0.05)$ higher concentrations of ascorbic acid compared to conventionally produced acerolas. Interestingly, the mean ascorbic acid content was significantly $(\mathrm{p}<0.05)$ higher in conventionally grown strawberries compared to organic strawberries. Vitamin A was significantly $(\mathrm{p}<0.05)$ higher in conventionally grown acerolas compared to organic acerolas. Overall, there was not a consistent pattern that can show organic fruits had more vitamin $\mathrm{C}$ or carotenoids than conventionally grown fruits. The researchers could not make a conclusion that one type of farming was better than the other when looking at these nutrients.

In sum, a general consensus is that there is insufficient evidence to say that organic foods have a higher nutrient content than conventionally produced food. The studies do agree, however, that there is less pesticide residue in organic foods. More long-term studies on human subjects are needed to determine health benefits of consuming organic foods versus conventionally produced foods.

\section{$\underline{\text { Opinions of farmers }}$}

Little evidence was found in the literature regarding the opinions of farmers about the nutrient content or health impact of organic versus conventionally produced food. Multiple searches in a variety of databases yielded minimal articles related to this topic. This appears to be an area that would require more research. It seems that it would be important to look at the farmers' views on the impact of farming method on nutrition. Their feelings on this subject could potentially influence them in their decision on what type of farm they are running. Just as consumers have opinions on organic foods and their health/nutrient benefits, farmers can have opinions as well. 


\section{Opinions of consumers}

Dahm et al. (2009) surveyed 443 students in a university in the southeastern United States using a 28-item questionnaire. This survey asked the students about awareness and knowledge of organic foods, attitudes about organic foods, purchasing of organic foods, and consumption behaviors regarding organic foods. The survey also asked about behaviors involving other environmentally friendly practices such as recycling and carpooling. The researchers found that students' attitudes toward organic foods were significantly related $(p<0.01)$ to their perception of whether they were following a healthy lifestyle. The attitudes were also significantly related $(\mathrm{p}<0.01)$ to the buying and purchasing behaviors of organic foods. In general, the researchers concluded that positive attitudes toward organic foods significantly predicted similar environmentally friendly behaviors. They also found that the students seemed to act on these positive behaviors based on the answers to the survey questions about purchasing organic foods.

Michaelidou and Hassan (2008) provided a questionnaire to 222 people on the Island of Arran in Scotland. The researchers aimed to look at health consciousness, food safety concerns and ethical self-identity, and to compare these factors to their attitudes toward organic produce and the intent to purchase organic produce. The researchers found that ethical self-identity and food safety concerns are significantly important factors that shape consumers' attitudes toward organic produce. Ethical self-identity significantly influenced intention to purchase. When looking at food safety, the main concerns participants reported were residue from fertilizers, additives, preservatives and chemical sprays. The researchers concluded that people who were ethically minded and concerned about food safety were likely to have more positive attitudes toward organic foods and have more intention of buying organic foods. 


\section{$\underline{\text { Summary }}$}

After reviewing many studies and review articles, there is still no definite evidence that organic foods are more healthful than conventionally grown food. Studies have shown that there was a higher content of pesticides in conventionally grown foods compared to organic foods. There were conflicting results from multiple studies on this topic. For example, one study showed that organic soybeans had higher content of some nutrients compared to conventionally grown food (Nakamura et al., 2007) while another study found no significant difference in nutrient content of carrot roots (Søltoft et al., 2011). Yet another study found mixed results when looking at nutrient content in three different organically and conventionally grown fruits from Brazil (Cardoso et al., 2011). Little evidence was found in the literature regarding the opinions of farmers about the nutrient content or health impact of organic versus conventionally produced food. Studies completed on the opinions of consumers showed that positive attitudes toward organic foods were significantly related to attitudes toward healthy lifestyles and other environmentally friendly behaviors (Dahm et al., 2009).

Most farmers are in business to provide food for the US populace. The beliefs and views of the farmer are important, but the farmer must sometimes consider the thoughts and needs of their consumers. If the consumers are saying that they want healthier food and believe that organic food is healthier, then the farmers may need to consider this when determining what farming method to choose to run their farm. Consumers are important to farmers because without consumers, they would have no income. The research shows that consumers have the opinion that organic food has more nutrition and health benefits. Although there is not enough scientific evidence to say that organic food has more nutrition, the literature shows that consumers believe this to be true. 


\section{Farming Method Related to the Environment}

\section{$\underline{\text { Scientific Evidence }}$}

The International Federation of Organic Agriculture Movements (IFOAM) reports that there are many benefits to organic agriculture (IFOAM Organic Basics, 2018). Organic agriculture takes a proactive approach to sustainability by helping with the soil, water, and air (IFOAM Organic Basics, 2018). To help with the soil, organic agriculture uses techniques such as crop rotations, inter-cropping, cover crops, and organic fertilizers to help with soil nutrients and to prevent erosion (IFOAM Organic Basics, 2018). Water is protected because organic agriculture eliminates synthetic fertilizers and pesticides and instead uses organic fertilizers such as composting and manure. This helps to reduce the risk for pollution of groundwater (IFOAM Organic Basics, 2018). Air is protected because organic agriculture decreases use of fossil fuels and non-renewable energy. Organic agriculture also uses processes such as cover crops and crop rotation, which can increase the return of carbon to the soil (IFOAM Organic Basics, 2018). The USDA agrees that organic agriculture can help with sustainability and references the same practices listed above (USDA Introduction to Organic Practices, 2015). Organic agriculture can have a positive impact on the environment in a multitude of ways (IFOAM Organic Basics, 2018; USDA Introduction to Organic Practices, 2015).

\section{Opinion of consumers}

Çabuk, Tanrikulu, \& Gelibolu (2014) administered a questionnaire to 385 consumers in Turkey. This survey examined the impact of health consciousness, environmental concern and food safety concern on attitudes toward organic food and likelihood of purchasing the organic food. The researchers found that as these concerns of health, environment and safety increased, 
there was a more positive attitude toward organic food and more intention of buying organic foods.

Dash, Samantaray \& Dash (2014) explored the knowledge of consumer awareness and perceptions towards organic foods and looked at how different variables related to the decisions to purchase the organic foods. These researchers gave 100 people a questionnaire which looked at organic food awareness, attitudes, and behaviors as well as the effectiveness of sources for organic information. Their results showed that factors such as "eco-friendly" and chemical or pesticide free were factors that had an impact on the decision-making process of purchasing organic foods. The researchers reported that the attitudes toward health, safety and environment were the most important factors that explained consumers' motivation to purchase organic foods. Selfa \&Qazi (2005) presented a case study that examined two counties in the state of Washington. These counties tried to bring organic produce into farmers markets in Seattle which was about 200 miles away. The researchers used a qualitative approach which included surveys and case study research with both producers and consumers. In one survey with consumers, they found that environmental factors were an important factor when making the decision to purchase organic food. However, other factors such as freshness, taste, and nutritional value were rated as higher importance more often.

Rabe \& Grobe (2005) conducted a phone survey with food shoppers in the state of Oregon. They were exploring the shoppers' knowledge and perceptions of organic foods. They interviewed 637 people. Their results showed that a household with members who were involved in environmental organizations were more likely to purchase organic foods more frequently. These researchers found that marketing campaigns that focused on benefits of organic foods, labeling them such as "earth friendly" and "home grown" could be a great 
promotor for organic foods. They found that organic food purchasers were usually more environmentally conscious. The research seemed to indicate a relationship between environmental attitudes and the purchase of organic foods.

\section{Opinions of farmers}

Darekar \& Naik (2017) conducted a study of 300 farmers (150 organic farmers and 150 conventional farmers) in Pune, Maharashtra, India, who raised crops such as grains, vegetables and fruits. The researchers gave the farmers an environmental attitude test. Organic farmers reported a greater awareness and appreciation for nature, and had a more positive relationship with the land than conventional farmers. The organic farmers had a significantly $(\mathrm{p}<0.01)$ higher, or more positive, environmental attitude compared to conventional farmers. The conventional farmers in this study reported more stress in their lives while the organic farmers showed more satisfaction with their lives and a stronger community connection. There was a significant difference $(\mathrm{p}<0.01)$ between the scores for psychological well-being between the two groups of farmers.

Thompson, A. W., Reimer, A., \& Prokopy, L. S. (2015) conducted research on 277 farmers in La Moine river watershed in western Illinois where soybeans and corn were raised. These researchers looked at environmental stewardship and profit maximization, and then compared this to the relationship between environmental attitudes and measure of various conservation methods. A survey was given to the farmers. Based on the results, the farmers were separated into four groups. The groups included: 1) low stewardship and moderate to high "farm as business" attitudes, 2) high stewardship and low "farm as business" attitudes, 3) high stewardship and high "farm as business" attitudes and 4) very high stewardship and very low 
"farm as business" attitudes. The researchers describe this term of "farm as business" as a view that places farm production and efficiency as the ultimate goal with an emphasis on maximizing yields. The researchers found that group one with the low stewardship and high "farm as business" views had the strongest disagreement with sustainable agriculture and environmental management goals with the mean responses to these planning items ranging from -0.7 to 1.4 . Groups two and three had much stronger support for these environmental goals. Group two's mean responses ranging from 0.3 to 1.6 and group three's mean responses ranging from 0.3 to 2.3. Group four had mean responses ranging from 1.0 to 2.2 showing that this group was most supportive of sustainable agriculture. What differed in these groups was their "farm as business" attitude. It seems from this research that having higher stewardship or positive environmental attitudes is a better predictor that farmers will support sustainable agriculture and more environmentally friendly practices.

Welsh \& Rivers (2011) conducted a study of 66 farmers in northern New York. These researchers used purposeful sampling to select farmers in this area to send a mail-in survey, which contained questions regarding farm structure, attitudes toward organic agriculture and biotechnology, and asked what conservation practices they are using. The researchers gathered the data and defined two groups: 1) large scale conservation farming and 2) alternative/ ecological farming. The larger scale conservation farmer in this study was defined as having higher sales on average, and used the following conservation practices: reduced tillage, legume rotation to enhance soil fertility, planting cover crops, crop rotation to break pest life cycles and using pest resistant crop varieties. The alternative/ecological farmers supported organic agriculture and used these conservation practices: certified organic production, intercropping, and cultivating for weed control. Conservation practice choices were influenced by whether the 
farmers grew their crops either organically or conventionally. The researchers concluded that attitudes and worldviews correlate with the type of environmental conservation practices used.

\section{Summary}

There is evidence that organic farming can have a positive effect on the environment by using many different methods to improve the air, water and soil (IFOAM Organic Basics, 2018; USDA Introduction to Organic Practices, 2015). By reviewing the research, it is evident that farmers who have more positive environmental attitudes are more likely to participate in organic farming practices (Darekar \& Naik, 2017; Thompson et al., 2015; Welsh \& Rivers, 2011). Research shows that consumer attitudes related to the environment can affect their behaviors such as purchasing organic food (Çabuk et al.,2014; Dash, Samantaray \& Dash, 2014; Selfa \& Qazi, 2005; Rabe \& Grobe, 2005).

\section{Review of Studies with Similar Theme and Design}

Koutsoukos \& Iakovidou (2013) used a mixed methods study to look at the attitudes and beliefs, which affected the farmers' choice of farming type in two different regions in Greece. The village of Foufas in Kozani was a conventional farming area, which had large farms, used industrial fertilizers and focused on quantity of production. Their main crops were potatoes, corn and wheat. The village of Kefalas in Sparta was an organic farming area, which had smaller farms, used organic fertilizer, and focused on quality of production. Their main crops were tomatoes and olive trees. The researchers first reviewed the history of agricultural evolution on both areas and then conducted structured and semi-structured 30-minute interviews with eight farmers from the two villages. The information from these interviews and the historical research 
was then used to create 48 Likert scale style questions for a survey given to more farmers in these areas. This data was then statistically analyzed. The findings showed that the most important factor in motivating the Kefalas farmers to have an organic farm was the belief that they will have quality produce. Another important motivating factor for these farmers was that by producing organic foods they would have a better income. The most influential factor for the Foufas farmers not choosing to run an organic farm was unfamiliarity with the practices of organic farming. The researchers discussed that conventional farmers should be provided with information about organic farming so that their unfamiliarity will not deter them from choosing to run on organic operation. The researchers also found environmental awareness to be an important factor to the organic farmers. Conventional farmers felt that the government did not give adequate motivation for them to change to an organic farming system. This research was done in Greece where the views of agriculture and products may be different from the United States. However, the structure of this research study is an interesting model. Also, the results showing the farmers' beliefs in quality produce, environmental views and also the unfamiliarity with organic processes are issues that can be carried over into any culture.

Lincoln and Ardoin (2016) conducted a study regarding environmental issues and sense of place in relation to sustainable farm practices in south Kona, Hawaii. The goal of this mixed methods study was to look at the importance of environmental values and sense of place of farmers related to their farming practices. The researchers conducted on-farm observations and interviews with 128 farmers in the town of Kona. These farmers were also given a survey, which was statistically analyzed. Important areas of farming practices that the researchers focused on were: environment, community, culture, education, and economics. They found a strong correlation of environmental values and sense of place that were aligned to type of 
farming practice. Both environmental values and sense of place independently had a significant linear correlation in relation to sustainable farming practices. They found that having high environmental values was a predictor of environmentally friendly practices.

Reimer et al. (2012) conducted a study which looked at the connection between environmental attitudes and conservation behaviors in farmers of Eagle Creek Watershed, Indiana. The researchers conducted 32 on-site interviews with the farmers where they discussed why they have or have not adopted certain conservation production systems. There were no organic producers interviewed in this study. The main crops grown by these farmers were corn and soybeans. The questions were open ended and promoted discussion. The conservation behaviors that were addressed in the interviews were: cover crops, conservation tillage, grassed waterways, filter strips, and pest control. The farmers were asked about usage of these systems and their familiarity with them. After reviewing the text from the interviews, there were three major themes in relation to the attitudes of the farmers: 1) off-farm environmental benefits; 2) responsibilities to others (or stewardship); and, 3) viewing the farm as a business (where the motive for farming is a profit generating business). Behavior regarding conservation practices was measured from low to high and graded by the number of conservation practices the farmer utilized. The researchers found that farmers who had attitudes consistent with off-farm benefits and stewardship used more conservation practices than farmers who viewed their farms as businesses and profit-making enterprises.

Grover and Gruver (2017) conducted a qualitative study which explored regional factors that had an influence on farmers' decisions. These researchers also explored barriers and opportunities which affected farm viability and sustainability. In this study, 15 key informants and 33 farmers from East Central Indiana were interviewed. Common themes emerged which 
were related to barriers these farmers believed affected sustainable farm management. These themes included: markets, structures and regulations, time and labor, environment/ecological factors, and networking and access to educational support. The researchers of this study concluded that regional factors played a role in the decisions these farmers made. Many farmers share common barriers, but this research indicates that external regional factors can affect farmers' attitudes and decisions regarding agricultural practices.

After reviewing these studies similar to the design of the current study, it is evident that important information can be gained from conducting on-site and face-to-face interviews. The first two studies presented were mixed methods studies, but the face-to-face interview was an important component. There is the potential for a rich source of data from interviewing farmers, and this dataset can be analyzed for emergent themes. These studies reported that environmental views impacted the thoughts and actions of the farmers interviewed and were reflected in how they ran their farms. These studies were conducted in different areas of the world, but still resulted with common themes of what influenced those farmers to use their farming methods.

\section{Summary}

There are many factors which could contribute to a farmer making the decision about what type of farming method to choose. There are conventional farms, certified organic farms and non-certified organic farms. The statistics show that the states of Indiana and Ohio have a low percentage of certified organic farms when compared to the total number of farms in the states. The literature presented explores connections between method of farming and human health/nutrient content of food and impacts to the environment. The research reviewed, which explored farmers' and consumers' attitudes, resulted in mixed outcomes. It is important to note 
that the research presented here indicates just a few of the factors which may influence a farmer's decision to choose their method of farming. More research must be done to determine what other factors could be affecting the attitudes of farmers when deciding whether to run a conventional, certified organic or non-certified organic farm. 


\section{CHAPTER 3}

\section{METHODOLOGY}

The purpose of this qualitative study was to explore the attitudes and factors that motivated farmers from Indiana and Ohio to operate either a certified organic, a non-certified organic, or a conventional farm, and to explore the interest of farmers in partnering with Registered Dietitian Nutritionists (RDNs) in educating consumers about the health benefits of eating fruit and vegetables to increase daily consumption. The researcher explored the farmers' thoughts regarding nutrition, health, environment, and working with RDNs to promote their products and improve the health of their communities. This chapter describes the methods used to conduct the study.

\section{Institutional Review Board}

Permission was obtained from Ball State University Institutional Review Board prior to implementing this study (Appendix A-1a). An application was submitted for an amendment to the original project which was approved by the Institutional Review Board (Appendix A-1b). The researcher conducting this study completed the Collaborative Institutional Training Initiative training (Appendix A-2). The research assistants who recorded the interviews completed the Individual Investigator Agreement form (Appendix A-3). The research assistants' roles were 
limited to operating the audio recording equipment during the interviews. They had no affiliation with Ball State University.

\section{Subjects}

Purposeful sampling was used to select 24 owners and/or operators of farms in Indiana and Ohio. The sample included eight farmers from each of the three farming methods:

conventional farmers, organic farmers, and non-certified organic farmers. Subjects and contact information were found by word of mouth and online via Google and Facebook searches. The farms were located in Indiana and Ohio within a 100-mile radius from Dayton, Ohio (See Figure 1).

\section{Instruments}

An Invitation to Participate Script (Appendix B-1) was used to invite potential subjects to join the study. The researcher for this study conducted in-person interviews with the farmers which were an average of 30-45 minutes in length. The open-ended questions (Appendix B-2) designed for these interviews were content validated by an expert panel, including the research committee. The demographic questionnaire (Appendix B-3) was also reviewed by the research committee. The interviews were recorded by a research assistant using an Olympus digital voice recorder WS-321M. The recorded interview files were transcribed and analyzed using QSR NVivo version 12. 


\section{Letter of Informed Consent and Demographic Questionnaire}

A letter of informed consent, approved by Ball State University IRB committee, was provided to each participant (Appendix C). The consent letter was reviewed and signed by each participant before the researcher commenced with the interview. These forms with the participants' signed names will be stored in a locked filing cabinet for up to three years and then will be destroyed. A demographic questionnaire (Appendix B-3) was also provided to the participant before the interview began. The participants filled out this questionnaire after they signed the informed consent page.

\section{Methods}

The researcher obtained contact information through word of mouth or the internet via Google and/or Facebook searches. The researcher called or emailed the farmers to invite them to participate in the study. If the invitation was extended via phone, the Invitation to Participate Script (Appendix B-1) was read to the potential subject, verbatim. If the invitation was extended via an email, the Invitation to Participate Script (Appendix B-1) was copied and pasted into the body of the email. A specific date and time was determined for each interview that was mutually agreeable to the farmer and researcher. The interviews all took place on the farmers' properties. The researcher and one research assistant were present at each of the 24 interviews. The interviews took place in a quiet area either outside or inside. All interviews were completed between the months of May and October. After informed consent (Appendix C) was acquired, and the demographic questionnaire (Appendix B-3) was completed by the participant, the interview commenced and lasted an average of 30-45 minutes. The shortest interview was 24 minutes 53 seconds and the longest interview was 1 hour and 8 minutes. The research assistant 
recorded the interview using the Olympus digital voice recorder WS-321M. The recorded interviews were kept on the researcher's computer that was password protected. After the study was completed, but not longer than 12 months, the interview recordings will be deleted.

\section{Data Analysis}

Each participant was assigned a random number to protect their identity. This identification number was used when analyzing the audio recordings and written texts. The recorded audio interviews were uploaded to the researcher's password protected computer. The files were transcribed by uploading the voice recordings to the QSR NVivo website voice to text transcription service. The transcripts were converted to Microsoft Word documents and saved to the researcher's password protected computer. The written transcripts were then reviewed by the researcher while listening to the recorded interviews to ensure there were no errors. When errors where identified, the researcher corrected them. No names were used on the transcripts.

Asterisks were used in the word document to replace any identifying information mentioned in the interview. The corrected and reviewed written transcripts were uploaded to QSR NVivo Version 12.

The researcher qualitatively analyzed the transcripts by using the constant comparative method (Glaser, 1965) resulting in nodes, or common themes in the NVivo program. The researcher reviewed each transcript, putting quotes from the participants into each node. Demographics were entered for each participant using the information from the demographic questionnaire filled out during the interview. This data was interpreted using the QSR NVivo version 12 matrix coding function which was used to cross reference the nodes between the different demographics. Demographic tables and charts were created using these functions in 
NVivo. The constant comparative method (Glaser, 1965) was used as the researcher was reading through transcripts. As new ideas or themes became apparent, the researcher added another node. These themes were moved into different categories as more information was gathered and more common themes because apparent. Nodes/themes and quotes were shared with the research team and input from the team was added to the analysis.

For data analysis validity and reliability, the researcher worked closely with the research advisor and committee. Peer debriefing was used to review all interviews, transcripts and interpretations of the data. In addition, during the interview process, the researcher frequently repeated information back to the farmers to verify that what they were saying was being interpreted correctly. The data analysis was reviewed multiple times and discussed regularly with the research advisor and committee for any feedback or changes needed.

\section{Summary}

This study explored the attitudes and factors that influenced a farmer to run a conventional, certified organic, or non-certified organic farm. Also explored were the farmers' thoughts about the environment, nutrition, health and the possibility of working with RDNs. A qualitative analysis was used to identify common themes and address the research questions. Individual face-to-face interviews with open-ended questions were conducted on the properties of 24 farmers. There were eight farmers from each farming type: conventional, certified organic, non-certified organic. The interviews were recorded by the research assistant using an Olympus digital voice recorder WS-321M device. The audio files were stored on the researcher's personal password protected computer. The interviews were transcribed using QSR NVivo's web-based transcription services. The data was then analyzed using QSR NVivo Version 12. Common 
themes were identified which guided the researcher to explore the attitudes and beliefs of these farmers as they related to farming method, health, environment, nutrition, and working with RDNs. 


\section{CHAPTER 4}

\section{RESULTS}

The purpose of this qualitative study was to explore the attitudes and factors that motivated farmers from Indiana and Ohio to operate either a certified organic, a non-certified organic, or a conventional farm, and to explore the interest of farmers in partnering with Registered Dietitian Nutritionists (RDNs) in educating consumers about the health benefits of eating fruit and vegetables to increase daily consumption. This chapter contains a summary of the findings for each research question, and participant demographics.

\section{Subjects}

There were 24 farmers interviewed for this study. Of these, there were eight conventional farmers, eight certified organic farmers and eight non-certified organic farmers. The farmers were all over age 18 and were the owner and/or operator of their farm. All farmers lived and farmed in either Indiana or Ohio, and were located within a 100-mile radius of Dayton, Ohio (See Figure 1). 


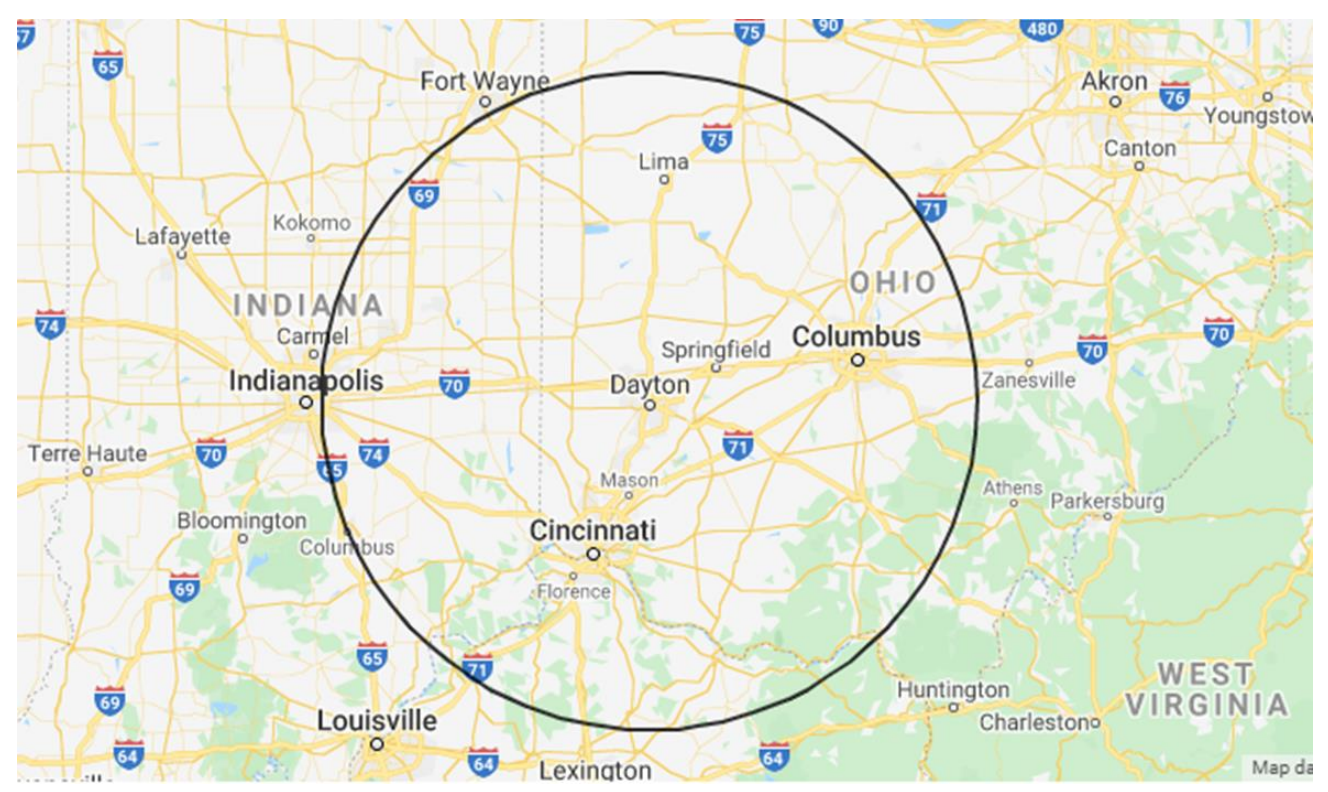

Figure 1: Location within a 100-mile radius of Dayton, Ohio

\section{Demographics}

Demographic information collected at the beginning of each interview included farmer demographics (gender, age, education level, years farming, farming full time or part time) and farm demographics (geographic location of the farm, annual gross sales, how many acres were farmed). There were a total of 24 farmers in this study. Of these, 18 were men and six were women. There were eight farmers from Indiana and 16 from Ohio. There were 13 farmers who farmed full-time, defined for this study as: the money obtained from running the farm was the farmer's sole source of income. There were 11 farmers who farmed as a secondary job, defined for this study as: the farmer received an income from another source besides the farm. The age range was between 28 and 80 years with a mean age of 49 years \pm 15 years. The participant demographics are listed in Table 1. 
Table 1: Sample Demographics

\begin{tabular}{|c|c|c|c|c|}
\hline$\underline{\text { Variable }}$ & $\frac{\text { Conventional }}{\underline{(n=8)}}$ & $\frac{\text { Certified Organic }}{\underline{(n=8)}}$ & $\begin{array}{l}\text { Non-Certified } \\
\text { Organic }(n=8) \\
\end{array}$ & $\frac{\text { Total }}{(\mathrm{n}=\mathbf{2 4})}$ \\
\hline \multicolumn{5}{|l|}{ Gender } \\
\hline Male & $87.5 \%$ & $75.0 \%$ & $62.5 \%$ & $75.0 \%$ \\
\hline Female & $12.5 \%$ & $25.0 \%$ & $37.5 \%$ & $25.0 \%$ \\
\hline \multicolumn{5}{|l|}{ State } \\
\hline Indiana & $12.5 \%$ & $37.5 \%$ & $50.0 \%$ & $33.3 \%$ \\
\hline Ohio & $87.5 \%$ & $62.5 \%$ & $50.0 \%$ & $66.7 \%$ \\
\hline \multicolumn{5}{|l|}{ Job Status } \\
\hline Full Time Job & $37.5 \%$ & $50.0 \%$ & $75.0 \%$ & $54.2 \%$ \\
\hline Secondary Job & $62.5 \%$ & $50.0 \%$ & $25.0 \%$ & $45.8 \%$ \\
\hline \multicolumn{5}{|l|}{ Education Level } \\
\hline High School & $62.5 \%$ & $25.0 \%$ & $12.5 \%$ & $33.3 \%$ \\
\hline 2-year college & $12.5 \%$ & $12.5 \%$ & $12.5 \%$ & $12.5 \%$ \\
\hline 4-year college & $12.5 \%$ & $50.0 \%$ & $37.5 \%$ & $33.3 \%$ \\
\hline Advanced Degree & $12.5 \%$ & 0 & $37.5 \%$ & $16.7 \%$ \\
\hline Other & 0 & $12.5 \%$ & 0 & $4.2 \%$ \\
\hline \multicolumn{5}{|l|}{ Gross Sales } \\
\hline Less than $\$ 25,000$ & $25.0 \%$ & $25.0 \%$ & $37.5 \%$ & $29.2 \%$ \\
\hline$\$ 25,001-\$ 49,999$ & $12.5 \%$ & 0 & $37.5 \%$ & $16.7 \%$ \\
\hline$\$ 50,000-\$ 99,999$ & $12.5 \%$ & $37.5 \%$ & 0 & $16.7 \%$ \\
\hline$\$ 100,000-\$ 249,0000$ & $12.5 \%$ & $37.5 \%$ & $12.5 \%$ & $20.8 \%$ \\
\hline$\$ 250,000-\$ 499,999$ & 0 & 0 & $12.5 \%$ & $4.2 \%$ \\
\hline$\$ 500,000-\$ 999,999$ & $25.0 \%$ & 0 & 0 & $8.3 \%$ \\
\hline More than $\$ 1,000,000$ & $12.5 \%$ & 0 & 0 & $4.2 \%$ \\
\hline
\end{tabular}


In general, the older the farmer, the longer the farmer had been operating their farm. There were two farmers over 40 years old who had been operating their farm for less than 10 years, however. There were some farmers who have been farming their entire lives (See Figure 2).

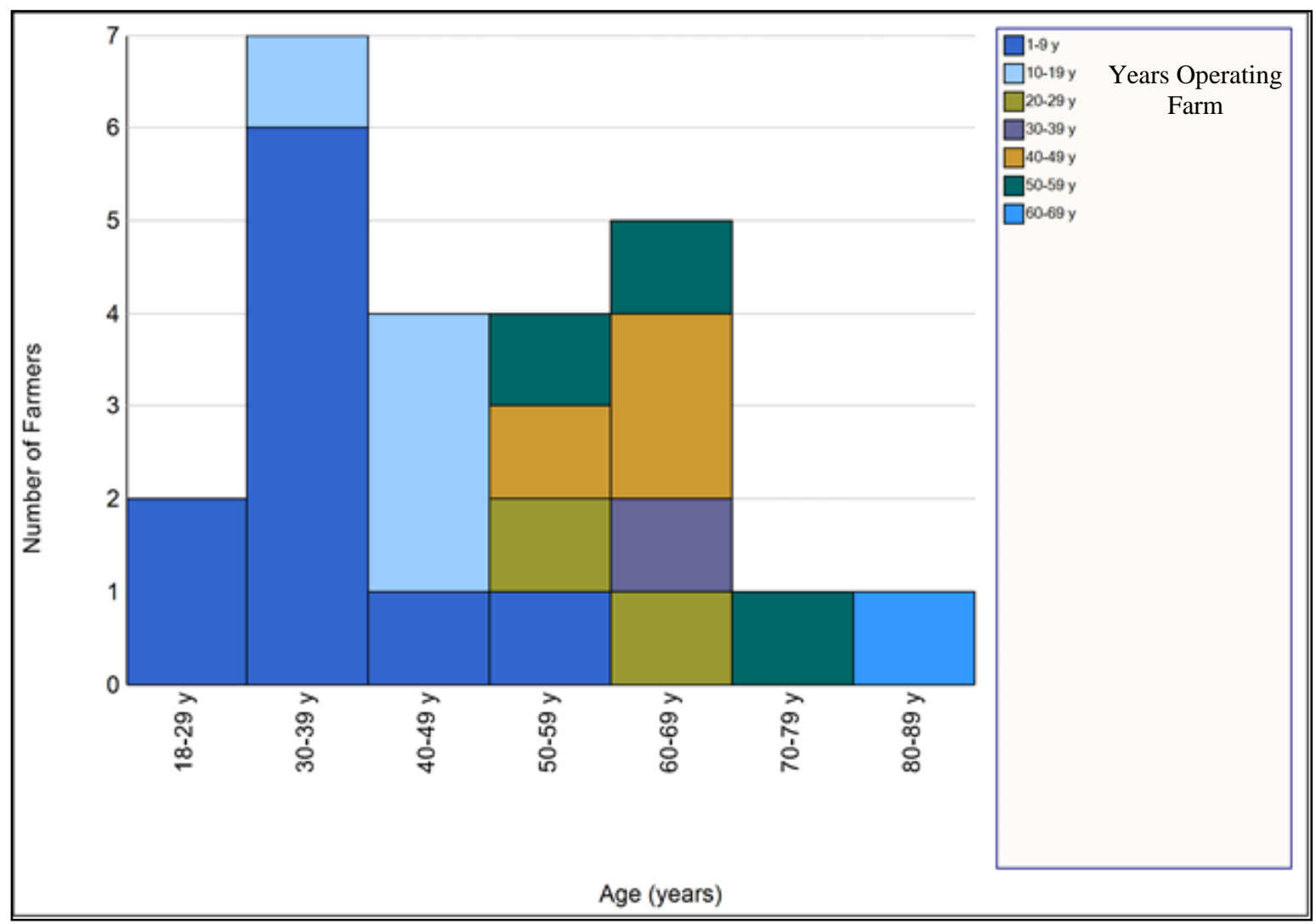

Figure 2: Age Range and Years Operating Farm

It was also common for the gross sales to increase as the number of acres farmed increased. One exception to this was a small farm with less than 50 acres that had a gross income between $\$ 500,000$ and $\$ 999,999$ (See Figure 3). 


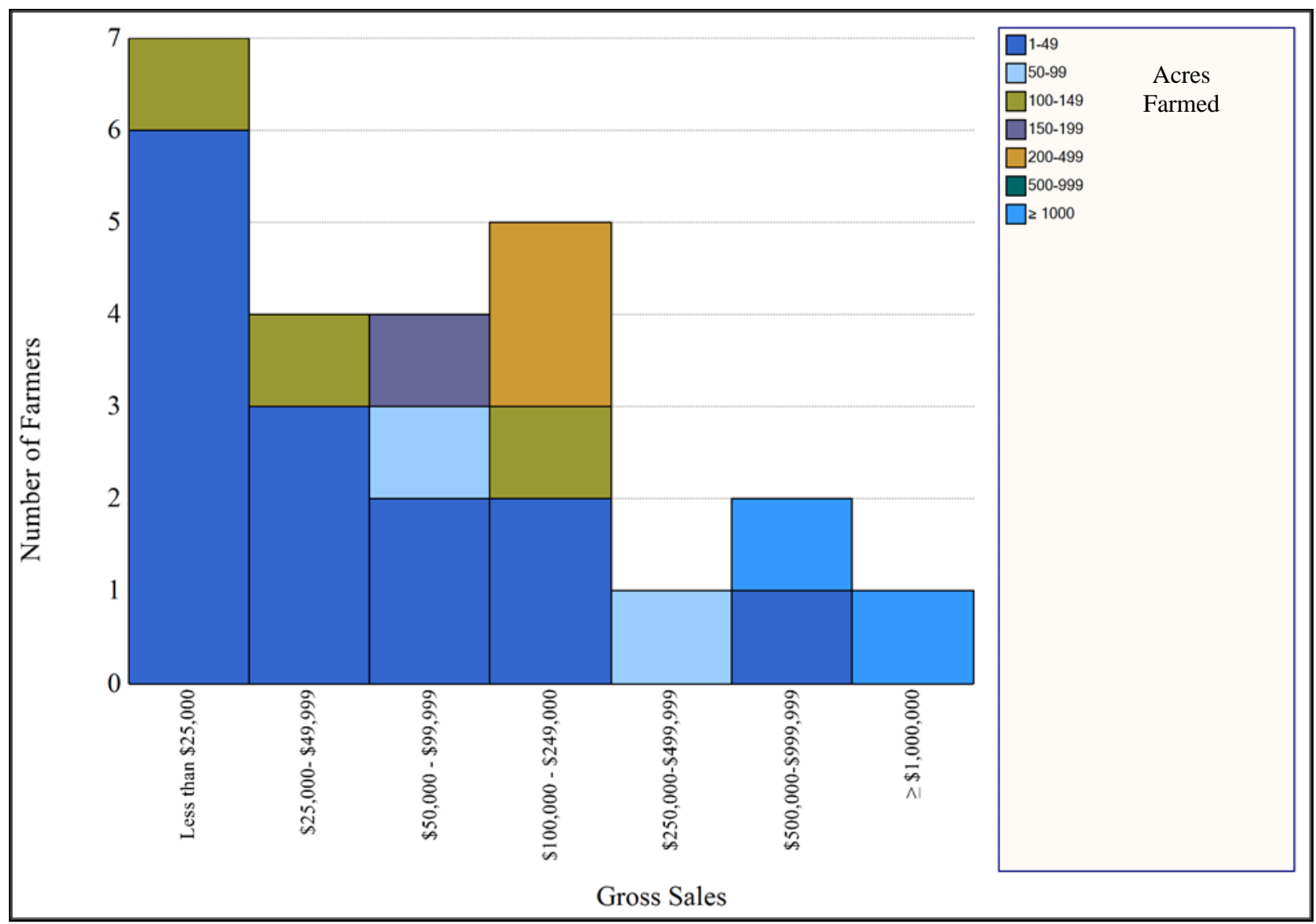

Figure 3: Gross Sales and Acres Farmed

\section{Main Themes and Subthemes}

After analyses of the data, using the constant comparative method (Glaser, 1965), main themes and subthemes became apparent. The main themes included: economics, environment, government, health/nutrition, and working with RDNs. Within each of these main themes, subthemes were discovered. All of the themes and subthemes are shown in Figure 4. 


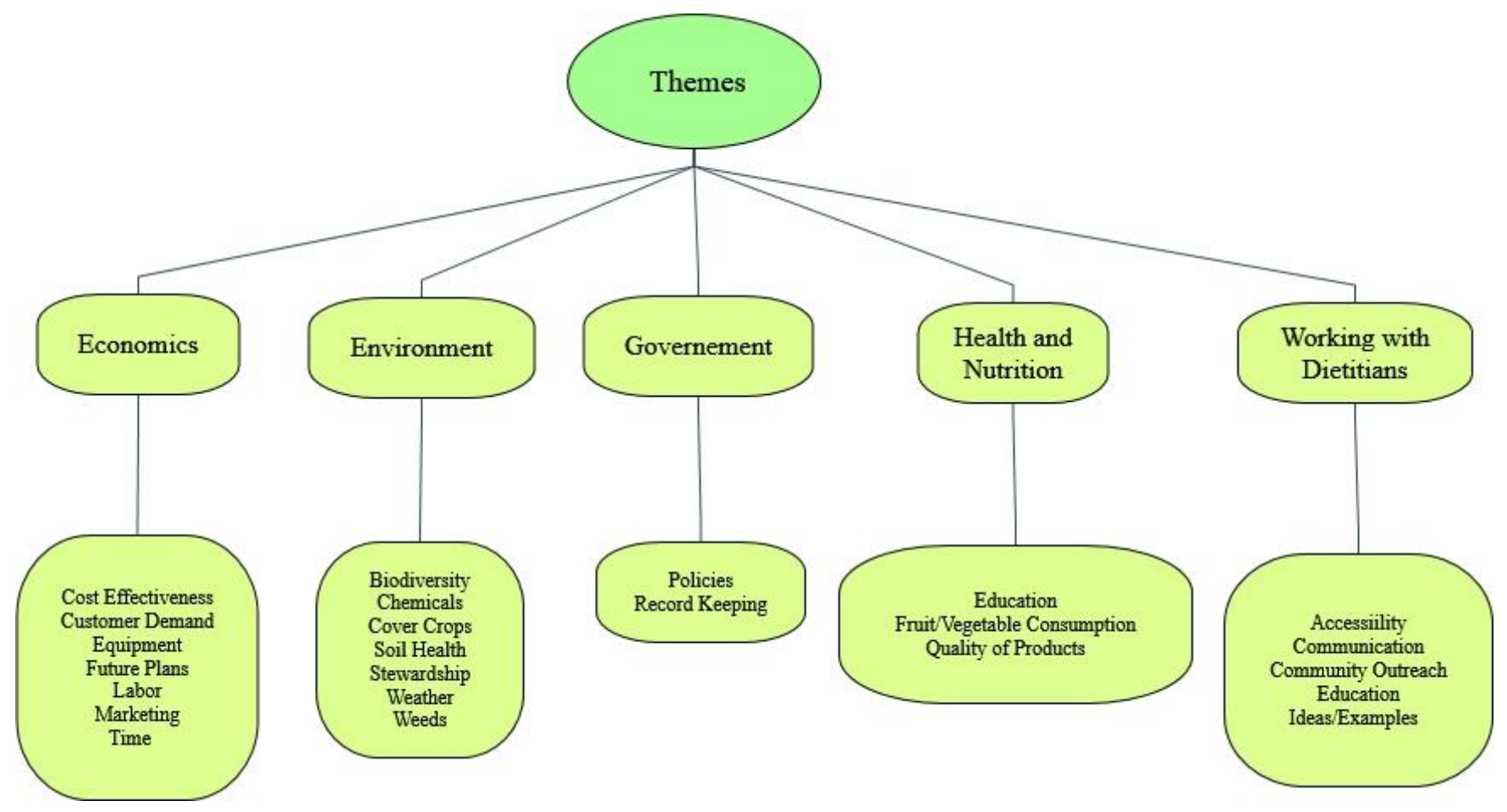

Figure 4: Main Themes and Subthemes

\section{RQ\#1: Factors Influencing Farming Methods}

The first research question of this study was "What factors influenced farmers to operate a certified organic, a non-certified organic, or a conventional farm?” Table 2 provides example quotes from the farmers on what motivated the farmers to use their specific type of farming method. 
Table 2: Quotes Associated with RQ\#1

\begin{tabular}{|c|c|c|c|}
\hline $\begin{array}{l}\text { RQ\#1: What factors influenced farmers } \\
\text { to operate a certified organic, a non- } \\
\text { certified organic, or a conventional farm? }\end{array}$ & $\begin{array}{l}\text { Type of } \\
\text { Farm }\end{array}$ & $\begin{array}{c}\text { Main } \\
\text { Theme(s) }\end{array}$ & Subtheme(s) \\
\hline $\begin{array}{l}\text { I also wanted to do something that would be } \\
\text { good ecologically for the environment. I } \\
\text { was concerned about environmental, } \\
\text { ecological issues, global warming, } \\
\text { herbicide, pesticide use, chemical... } \\
\text { excessive chemical use and so I wanted to } \\
\text { do something that would be good for the } \\
\text { land as well. }\end{array}$ & $\begin{array}{l}\text { Non-certified } \\
\text { organic }\end{array}$ & Environment & Chemicals \\
\hline $\begin{array}{l}\text { Because I mean I started it for } \\
\text { environmental reasons and like health you } \\
\text { know for the people who we're feeding. } \\
\text { You know, I mean I don't want to eat } \\
\text { produce that's been sprayed with herbicides } \\
\text { and pesticides or fungicides or whatever and } \\
\text { I don't want to feed that to people that...to } \\
\text { our customers and CSA members. }\end{array}$ & $\begin{array}{l}\text { Non-certified } \\
\text { organic }\end{array}$ & $\begin{array}{l}\text { Environment } \\
\text { Health/Nutrition }\end{array}$ & $\begin{array}{l}\text { Chemicals } \\
\text { Quality of } \\
\text { Products }\end{array}$ \\
\hline $\begin{array}{l}\text { That's my biggest thing. I grow not just to } \\
\text { make money. Yeah. We all, we're in it for } \\
\text { profit. But I grow because I want people to } \\
\text { have good vegetables to eat... It's not the } \\
\text { money. Because I make it all right money } \\
\text { but it's not...I'm never gonna be rich. I do it } \\
\text { because I enjoy doing it and I enjoy selling } \\
\text { vegetables. It's a joy and pleasure to see } \\
\text { smiles on people's faces. That's the reason } \\
\text { why I do it. }\end{array}$ & $\begin{array}{l}\text { Non-certified } \\
\text { organic }\end{array}$ & $\begin{array}{l}\text { Health/Nutrition } \\
\text { *Sense of } \\
\text { Community } \\
\text { (Additional } \\
\text { Findings) }\end{array}$ & $\begin{array}{l}\text { Quality of } \\
\text { Products }\end{array}$ \\
\hline $\begin{array}{l}\text { I just feel like it's the way things are } \\
\text { supposed to be grown and I feel like I'm } \\
\text { providing a high quality product to people. } \\
\text { And... which they appreciate and I think it's } \\
\text { beneficial. }\end{array}$ & $\begin{array}{l}\text { Certified } \\
\text { Organic }\end{array}$ & Health/Nutrition & $\begin{array}{l}\text { Quality of } \\
\text { Products }\end{array}$ \\
\hline $\begin{array}{l}\text { But I feel like it's good for the environment. } \\
\text { I feel like it's better than conventional. } \\
\text { Sometimes that's hard to remember if you } \\
\text { got a lot of weeds and you look out there } \\
\text { and you want to get sick. But I think it is } \\
\text { better. }\end{array}$ & $\begin{array}{l}\text { Certified } \\
\text { Organic }\end{array}$ & Health/Nutrition & $\begin{array}{l}\text { Quality of } \\
\text { Products }\end{array}$ \\
\hline $\begin{array}{l}\text { So conventional is for the labor input you } \\
\text { put into it, it's about the best bang for the } \\
\text { buck as far as that goes. }\end{array}$ & Conventional & Economics & $\begin{array}{l}\text { Cost } \\
\text { Effectiveness } \\
\text { Labor }\end{array}$ \\
\hline
\end{tabular}




\begin{tabular}{|l|l|l|l|}
\hline $\begin{array}{l}\text { Our farm is our livelihood totally. And so } \\
\text { economics dictates that we do what we do. }\end{array}$ & Conventional & Economics & $\begin{array}{l}\text { Cost } \\
\text { Effectiveness }\end{array}$ \\
\hline $\begin{array}{l}\text { I mean I could spend more... I could quit } \\
\text { my job in town and then I have more time to } \\
\text { cultivate and take care of weeds. But I } \\
\text { chose not to do that. }\end{array}$ & Conventional & Economics & Time \\
\hline $\begin{array}{l}\text { Well I guess a lot of that is if I didn't use } \\
\text { chemicals to kill weeds I'd have a lot of } \\
\text { weeds and I wouldn't have much crop to } \\
\text { harvest. }\end{array}$ & Conventional & Economics & $\begin{array}{l}\text { Cost } \\
\text { Effectiveness }\end{array}$ \\
\hline $\begin{array}{l}\text { Because we're such a small acreage farm, } \\
\text { we have to maximize our potential for } \\
\text { having a crop. So if I do see a problem I } \\
\text { will address it. I'm not going to let my } \\
\text { strawberry crop go to pieces if I...if there's } \\
\text { something I can do about it. }\end{array}$ & Conventional & Economics & Cost \\
\hline $\begin{array}{l}\text { You know if it could be a perfect storm, you } \\
\text { know, and I didn't have to ever spray, why } \\
\text { sure. Heck yeah. That'd be great. }\end{array}$ & Conventional \\
\hline
\end{tabular}




\section{Economics (Main Theme)}

For conventional farmers, time, money and running the business were major drivers of what made them use chemicals and farm in a conventional way. These conventional farmers commented that the chemicals saved them time and were more convenient. Conventional farmers believed that if they did not use chemicals, it would take more time to manage the weeds and keep their yields up. These conventional farmers expressed that they could not afford to lose their products. The conventional farmers believed they had to use chemicals to prevent insects from reducing their yields, which would cause them to lose money. One conventional farmer stated, "Our farm is our livelihood. And so economics dictates that we do what we do." Certified and non-certified organic farmers did not have as much of a focus on money and business. These certified and non-certified organic farmers did discuss their marketing strategies and how the products were sold, but overall, the certified and non-certified organic farmers commented more about the environment and health. One attitude all three types of farmers had in common was that they were trying to farm efficiently and be cost effective in whatever methods they used. None of the farmers in this study wanted to waste resources.

\section{Environment (Main Theme)}

The data showed that none of the conventional farmers necessarily liked to use pesticides and/or herbicides, but these conventional farmers believed it was necessary to protect their crops from pests and to maintain their yields. Although the conventional farmers used chemicals, they all were conscious of how their actions affected the environment. These conventional farmers also made decisions based on preventing erosion and keeping the soil healthy so it would continue to produce healthy crops. The certified and non-certified organic farmers used organic 
methods because they wanted to avoid chemical use to protect the environment and the land. The certified and non-certified organic farmers also focused on preventing erosion and promoting soil health. The environment was a factor in the decision-making process for every farmer of this study. This is further discussed in research question two.

\section{Health and Nutrition (Main Theme)}

The certified and non-certified organic farmers in this study did not want to feed consumers products that were sprayed with chemicals due to the potential negative health impact. The environment and protecting the health of the consumers by not using any form of chemicals were the main drivers in what motivated these certified and non-certified organic farmers to farm organically. The goals of the certified and non-certified organic farmers were to grow their products in a way that would protect the environment and provide products that would promote health to their consumers. Even though farmers who use organic methods may need to spend more time dealing with weeds, these farmers believed that not using chemicals was the way to keep their consumers healthy and provide nutritious products. Although the conventional farmers did believe that good nutrition is important for overall health of consumers, they continued to use chemicals. These conventional farmers were concerned about the stability of their business and did not see organic farming methods as an alternative due to the high cost and increased time commitments. One conventional farmer said, "Anybody who has a mortgage or payroll is going to spray if he has to." To these conventional farmers, cost and time were more valued than the potential negative health impacts of chemicals. The larger scale conventional farmers believed that they were promoting health by providing food for the world. 


\section{Additional Findings}

Of the farmers interviewed, $67 \%$ were raised on a farm and grew up farming. This percentage was a mixture of conventional, certified and non-certified organic farmers. All of the farmers who grew up on a farm were proud of that fact. Some had a long history with their land. One conventional farmer even stated that his farm was:

Kind of continuance of the legacy set by great grandpa. And just, you know, you have a family farm especially when you've got land that's been in the family for three generations and now going on a fourth generation. So it's something that you of take a lot of pride in making sure it continues.

Of the $33 \%$ of farmers who did not grow up on a farm, there were a variety of factors that influenced them to become farmers. One non-certified organic farmer did not want to work in an office job anymore and wanted to be outdoors, so farming appealed to him. Another certified organic farmer was inspired to farm after volunteering and seeing neighborhoods that were in food deserts. That farmer wanted to help provide fresh produce for people in areas that were classified as food deserts. Another non-certified organic farmer felt compelled to begin farming in order to provide nutritious food to hungry children and their families. This farmer volunteered at a school and talked to a child who could only go to the food bank on the fifteenth of each month for food. This farmer grew fresh produce and donated it to children and families in need to help supplement what they could get at food banks. 


\section{RQ\#2: Impact on the Environment}

The second research question was, "How do the farmers view the impact they have on the environment?" Every farmer mentioned the environment throughout their interview, no matter the type of farming methods used. Table 3 provides example quotes from the farmers on their attitudes and beliefs about the potential impact they have on the environment. 
Table 3: Quotes Associated with RQ\#2

\begin{tabular}{|c|c|c|c|}
\hline $\begin{array}{l}\text { RQ\#2: How do the farmers view the impact } \\
\text { they have on the environment? }\end{array}$ & $\begin{array}{l}\text { Type of } \\
\text { Farm }\end{array}$ & $\begin{array}{c}\text { Main } \\
\text { Theme(s) }\end{array}$ & Subtheme(s) \\
\hline $\begin{array}{l}\text { Well I try not to have much effect at all. I try } \\
\text { as I said try to keep the ecosystem the way it } \\
\text { is. I try not to destroy, completely destroy one } \\
\text { pest or what have you. and it's all, you know, } \\
\text { it's all connected. }\end{array}$ & $\begin{array}{l}\text { Non-certified } \\
\text { organic }\end{array}$ & Environment & Biodiversity \\
\hline $\begin{array}{l}\text { So I do a lot of beneficial pollinator and } \\
\text { beneficial insect flower beds and different } \\
\text { things throughout the property as well. }\end{array}$ & $\begin{array}{l}\text { Non-certified } \\
\text { organic }\end{array}$ & Environment & Biodiversity \\
\hline $\begin{array}{l}\text { The soil is beautiful. The soil used to be worn } \\
\text { out, conventional farming soil that had been } \\
\text { just abused for years. And I put manure on it } \\
\text { for } 35 \text { years. And now it's just delicious. } \\
\text { There's one advantage. Another advantage is } \\
\text { as the soil gets better, you get fewer diseases } \\
\text { and problems. }\end{array}$ & $\begin{array}{l}\text { Non-certified } \\
\text { Organic }\end{array}$ & Environment & Soil Health \\
\hline $\begin{array}{l}\text { Weed control. Although we've gotten a lot } \\
\text { better about that, or at that, over the years. } \\
\text { I've developed a variety of different techniques } \\
\text { to better manage the weeds... }\end{array}$ & $\begin{array}{l}\text { Non-certified } \\
\text { Organic }\end{array}$ & Environment & Weeds \\
\hline $\begin{array}{l}\text { I'm trying to prevent erosion. I mean you } \\
\text { know, the biggest water pollutant is soil itself. } \\
\text { So trying to prevent erosion through cover } \\
\text { crop use. And just making sure things are } \\
\text { covered all the time. }\end{array}$ & $\begin{array}{l}\text { Certified } \\
\text { Organic }\end{array}$ & Environment & $\begin{array}{l}\text { Soil Health } \\
\text { Cover Crops }\end{array}$ \\
\hline $\begin{array}{l}\text { Our soil's healthier. We're not eroding the } \\
\text { earth. We're building organic matter, not } \\
\text { using it. }\end{array}$ & $\begin{array}{l}\text { Certified } \\
\text { Organic }\end{array}$ & Environment & Soil Health \\
\hline $\begin{array}{l}\text { The soil is a living organism. You can't } \\
\text { poison it and expect it to be healthy and grow } \\
\text { good crops. }\end{array}$ & $\begin{array}{l}\text { Certified } \\
\text { Organic }\end{array}$ & Environment & Soil Health \\
\hline $\begin{array}{l}\text {... some weather events can be out of your } \\
\text { control, but I believe it's your job to minimize } \\
\text { the impact of those weather events }\end{array}$ & $\begin{array}{l}\text { Certified } \\
\text { Organic }\end{array}$ & Environment & Weather \\
\hline $\begin{array}{l}\text { We try to be a steward of the land...that we try } \\
\text { to take care of the land... So that's part of } \\
\text { being a good steward of the land, the taking } \\
\text { care of it. }\end{array}$ & Conventional & Environment & Stewardship \\
\hline
\end{tabular}




\begin{tabular}{|l|l|l|l|}
\hline $\begin{array}{l}\text { I think erosion is the biggest. People didn't } \\
\text { realize that erosion in this country is the } \\
\text { biggest concern for farming. Should be the } \\
\text { biggest concern for farming. }\end{array}$ & Conventional & Environment & Soil Health \\
\hline $\begin{array}{l}\text { We do exercise caution of not spraying over } \\
\text { top of moving water and taking some } \\
\text { precaution and not allow these chemicals in } \\
\text { certain areas... }\end{array}$ & Conventional & Environment & Chemicals \\
\hline
\end{tabular}

\section{Biodiversity (Subtheme)}

Certified and non-certified organic farmers mentioned more often than conventional farmers that biodiversity was an important factor in making decisions about their farming methods. Since these certified and non-certified organic farmers did not use chemicals, there were more insects and animals on their properties. These certified and non-certified organic farmers were proud of the biodiversity found on their farms and promoted biodiversity because they believed that biodiversity showed their farm was thriving and was healthier. The certified and non-certified organic farmers would even plant flowers to attract beneficial insects and pollinators. They commented that the variety of wildlife and insects was important to them and the environment. As opposed to conventional farmers, certified and non-certified organic farmers found very creative ways to deal with insects and keep animals from eating their products. One non-certified organic farmer explained how he kept racoons out of his corn:

What I do is I put two solar radios out in my sweet corn. And they think people are out there and they won't come out. And the same with the deer. That's your, that's the way to stop deer. Just put two radios out near the corn crop... 


\section{Chemicals (Subtheme)}

The farmers interviewed, no matter the farming method, had strong opinions about trying to keep chemicals and pollution out of the waterways. The certified and non-certified organic farmers did not use chemicals at all, and a major motivator for that decision was to protect the environment and improve soil health. Conventional farmers tried to be responsible with their chemical use and followed the recommended regulations for spraying. These conventional farmers expressed that they tried to limit the use of chemicals because of potential negative effects on the environment. One conventional farmer even stated, "One thing that I try to stay away from Roundup as much as I can. I do use it but I don't use it as much as other people do." The conventional farmers were conscious of the number of times they sprayed their crops and monitored the weather conditions closely. All of the farmers interviewed, regardless of their farming method, agreed that the environment was a factor in their farming decisions and it was important to protect it. Even if they used chemicals, the farmers expressed they did so in as safe a method as possible.

\section{Cover Crops (Subtheme)}

Fifteen out of the 24 farmers interviewed (63\%) mentioned using some kind of cover crop. Of these, 13 farmers were certified or non-certified organic farmers, and the other two farmed conventionally. The fifteen farmers who used cover crops did so for a variety of reasons, commenting that cover crops could affect the environment by: preventing erosion, building organic matter in the soil, and improving the nutrient content of the soil. Another benefit to these farmers using cover crops was weed suppression. Many of the farmers had a rotation of various types of cover crops to put different nutrients in the soil throughout various times of the 
year. The certified and non-certified organic farmers were very in tune with the importance of cover crops in protecting the environment and promoting soil health.

\section{Soil Health (Subtheme)}

Twenty-one out of the 24 farmers interviewed (88\%) commented on soil health. Soil health was important to the farmers because the soil helped them to grow their crops. The certified and non-certified organic farmers believed their soil was healthier than conventional farming soil because there were more insects and worms in it. Some certified and non-certified organic farmers even stated the nutrient levels of their soil were higher than conventionally farmed soil. Crop rotation was an important part of keeping the soil healthy. The certified and non-certified organic farmers with a variety of fruit and vegetable crops practiced this more often during one growing season because of the quick turnover. The conventional farmers rotated each season between their major crops. Another focus that was consistent in each farming type was preventing erosion. Fifteen out of the 24 farmers interviewed (63\%) mentioned the use of some sort of cover crop to protect the soil and avoid erosion. Every farmer interviewed agreed that the soil was one of the most important assets of their farm. They wanted to take good care of the soil and keep it healthy in order to produce healthy crops.

\section{Stewardship (Subtheme)}

Five out of the 24 farmers interviewed (21\%) commented on land stewardship. Of these, three were conventional farmers and the other two were organic. These five farmers said that one of their goals was to be a good steward of the land. These farmers explained the importance of taking care of their piece of land that they are in control of, no matter the size of their farms. 
These farmers who commented on land stewardship explained that it is important to protect the waterways, the soil, and the environment. These were the only five farmers that specifically used the term "good steward". One conventional farmer explained very clearly the reason why being a good steward of the land is important:

So that tells me that we're doing something right with our primary resource which is our land. We're taking care of it. We pour everything into it. And it is just...again that's part of what we breathe and think every day. We've gotta take care of this because it has to sustain us and support us.

\section{Weather (Subtheme)}

Every farmer mentioned weather in some way during the interviews. Most farmers commented on the major weather changes that affected their farming, such as excessive rain and extensive dry periods. These weather events affected the way all the farmers worked because if it was too wet, they either could not plant in time or the crops that were already planted drowned. If it was too dry, the crops would not do well and it could reduce total yields. In order to combat this, the farmers came up with strategies to adapt to the changing weather conditions and maximize their yields. Rotating crops to different beds, using high tunnels, irrigation systems, field tiles and row cover crops, improving soil quality, and adjusting planting times were ways to deal with the weather. One non-certified organic farmer used hay bales to plant tomatoes in order to protect them from weather events. It took years to perfect their plans and strategies. The weather was one factor that the farmers commented was always out of their control, but they were constantly trying to work with it and adapt in order to have improved yields. 


\section{Weeds (Subtheme)}

All of the farmers had to decide how they would deal with weeds. The conventional farmers chose to use chemicals to help kill weeds and keep their yields up. Weed control was a factor for why conventional farmers farmed the way they did. They were afraid if they did not use chemicals, the weeds would affect their crop yields and they would lose money. Certified and non-certified organic farmers had to deal with weeds in a completely different way since they could not use synthetic chemicals. There were a few organic sprays that were allowable to the organic farmers, but most of the farmers in this study expressed that these sprays did not work well. Instead, they had to take more time to hand weed or come up with other creative solutions for weed control. Many of the certified and non-certified organic farmers used cover crops to help suppress weeds. Some of these organic farmers used other tactics such as mulching, plastic coverings, crop rotation, and even flame weeding.

\section{RQ\#3: Impact on Health}

The third research question was, "How do the farmers view the impact they have on the health and wellbeing of their consumers?" Table 4 provides example quotes from the farmers about their thoughts on the potential impact they have on the health of the consumers. 
Table 4: Quotes Associated with RQ\#3

\begin{tabular}{|c|c|c|c|}
\hline $\begin{array}{l}\text { RQ\#3: How do the farmers view the } \\
\text { impact they have on the health and } \\
\text { wellbeing of their consumers? }\end{array}$ & $\begin{array}{l}\text { Type of } \\
\text { Farm }\end{array}$ & Main Theme(s) & Subtheme(s) \\
\hline $\begin{array}{l}\text { We've had lots of customers who've joined } \\
\text { our CSA program and they say like after... } \\
\text { after the summer they like they had like a } \\
\text { doctor checkup and it's like they lost } \\
\text { weight, their like blood pressure was down } \\
\text { and like I don't know lots of positive things } \\
\text { and they kind of mostly attributed it to the } \\
\text { fact that they were in like a CSA and it was } \\
\text { helping them eat more vegetables... }\end{array}$ & $\begin{array}{l}\text { Non-certified } \\
\text { organic }\end{array}$ & Health/Nutrition & $\begin{array}{l}\text { Fruit and } \\
\text { vegetable } \\
\text { consumption }\end{array}$ \\
\hline $\begin{array}{l}\text { I want to hone in to what's going to grow } \\
\text { best here that I can grow well and it has a } \\
\text { nutritional value. Because if I'm going to } \\
\text { donate food...it's...to me it's not going to } \\
\text { do any good if I'm gonna donate something } \\
\text { that's nutritionally empty }\end{array}$ & $\begin{array}{l}\text { Non-certified } \\
\text { Organic }\end{array}$ & Health/Nutrition & $\begin{array}{l}\text { Quality of } \\
\text { Products }\end{array}$ \\
\hline $\begin{array}{l}\text { I get the general sense that most people } \\
\text { avoid fruits and vegetables either because of } \\
\text { their preference or because of the cost. }\end{array}$ & $\begin{array}{l}\text { Certified } \\
\text { Organic }\end{array}$ & Health/Nutrition & $\begin{array}{l}\text { Fruit and } \\
\text { vegetable } \\
\text { consumption }\end{array}$ \\
\hline $\begin{array}{l}\text { Everybody chooses what they put in their } \\
\text { mouths. So I think education has a lot to } \\
\text { help with that. }\end{array}$ & $\begin{array}{l}\text { Certified } \\
\text { Organic }\end{array}$ & Health/Nutrition & Education \\
\hline $\begin{array}{l}\text { And on a you know, a more intimate level, } \\
\text { I'm growing good nutritious food for } \\
\text { people. And the more they eat of it, the } \\
\text { healthier they're going to be in my opinion. }\end{array}$ & $\begin{array}{l}\text { Certified } \\
\text { Organic }\end{array}$ & Health/Nutrition & $\begin{array}{l}\text { Fruit and } \\
\text { vegetable } \\
\text { consumption } \\
\text { Quality of } \\
\text { products }\end{array}$ \\
\hline $\begin{array}{l}\text { I also believe that people want to be more } \\
\text { educated and you know, education helps } \\
\text { them be more healthy about what they're } \\
\text { eating. When they know where it comes } \\
\text { from, they can ask questions about it. }\end{array}$ & Conventional & Health/Nutrition & Education \\
\hline $\begin{array}{l}\text { And I do it for health reasons. I do it and } \\
\text { try to stay away from the chemicals as } \\
\text { much as I can. }\end{array}$ & Conventional & Health/Nutrition & $\begin{array}{l}\text { Quality of } \\
\text { products }\end{array}$ \\
\hline
\end{tabular}




\begin{tabular}{|l|l|l|l|}
\hline $\begin{array}{l}\text { I'm really kind of amazed that people are } \\
\text { not thinking about what they put in their } \\
\text { mouth and giving a little bit of thought } \\
\text { about where did this come from? How was } \\
\text { it raised? Is it fresh? It's just food. }\end{array}$ & Conventional & Health/Nutrition & $\begin{array}{l}\text { Quality of } \\
\text { products }\end{array}$ \\
\hline $\begin{array}{l}\text { I think that a person should eat a healthy, } \\
\text { described nutritional diet every day. It's } \\
\text { just, it's very important. }\end{array}$ & Conventional & Health/Nutrition & $\begin{array}{l}\text { Fruit and } \\
\text { vegetable } \\
\text { consumption }\end{array}$ \\
\hline
\end{tabular}

\section{Education (Subtheme)}

The farmers in this study believed that if people were more educated on the benefits of fresh produce, they may eat healthier. The farmers mentioned often that educating young children about where food comes from might result in these children understanding that a healthy diet is important. The farmers suggested that the parents needed to be educated also to provide a healthful diet for their families. There was one conventional farmer who regularly invited school groups to the farm. This farmer gave tours of the farm to educate children about where food comes from and how it is grown. The certified and non-certified organic farmers who sold at farmers markets attempted to educate people about their products by talking to them and sometimes provided recipes to encourage intake of the fresh produce.

\section{Fruit and Vegetable Consumption (Subtheme)}

All of the farmers in this study recognized that fresh produce was a very important part of a healthy diet, and tried to promote this to the public. All the farmers agreed that people in Indiana and Ohio were not meeting the USDA recommended daily servings of fruits and vegetables. The farmers stated people were not meeting this recommendation because of convenience foods, fast foods and not knowing how to prepare healthy meals. One farmer commented that people do not sit down and eat family meals together anymore, so fruit and 
vegetable intake has decreased. Other farmers mentioned that people are very busy and on the go, so time could be a factor which is affecting fruit and vegetable intake. Still other farmers discussed that the cost of fresh produce could be a factor that affected intake of fruits and vegetables. The farmers discussed making sure everyone had access to healthy produce, as this could be a barrier to fruit and vegetable consumption as well. The farmers who had CSA programs felt that they were helping to improve customers' consumption of fruits and vegetables by providing boxes of produce each week. These farmers wrote newsletters and provided recipes to help encourage intake of their products.

\section{Quality of Products (Subtheme)}

All the farmers interviewed were in some way concerned about human health. They grew crops that affected the health of humans either by direct consumption, or consumption of meats or other products. The conventional farmers recognized that the chemicals were not good for human health, but sometimes it was necessary to use them to save their crops. The commodity farmers tried to grow nutritious products for whomever they were selling, understanding the original raw product that was potentially going into a processed food had an effect on health. The certified and non-certified organic farmers who sold at farmers markets often learned about food safety practices. These farmers would take classes and learn about the rules for food safety to ensure they would not harm their consumers. After completing the classes, these farmers followed all recommendations when harvesting and processing their products before taking them to market. 


\section{RQ\#4: Policies That Affect Farming}

The fourth research question was, "Are there farming related polices in Indiana, Ohio and nationally that support or create a barrier to farming?" Table 5 provides example quotes from the farmers on their thoughts about government policies and regulations.

Table 5: Quotes Associated with RQ\#4

\begin{tabular}{|l|l|l|l|}
\hline $\begin{array}{l}\text { RQ\#4 Are there farming related polices in } \\
\text { Indiana, Ohio and nationally that support or } \\
\text { create a barrier to farming? }\end{array}$ & $\begin{array}{c}\text { Type of } \\
\text { Farm }\end{array}$ & $\begin{array}{c}\text { Main } \\
\text { Theme(s) }\end{array}$ & Subtheme(s) \\
\hline $\begin{array}{l}\text {...How small I am, on my scale, there's not } \\
\text { much...But like just selling at a farmers markets } \\
\text { and stuff, there's not a whole lot of regulations. }\end{array}$ & $\begin{array}{l}\text { Non-certified } \\
\text { Organic }\end{array}$ & Government & Policies \\
\hline $\begin{array}{l}\text { I tried to go the organic certified route and I have } \\
\text { commodities farmers of corn and soybeans to } \\
\text { close to my property. So I cannot grow and be } \\
\text { certified organic on paper. }\end{array}$ & $\begin{array}{l}\text { Non-certified } \\
\text { Organic }\end{array}$ & Government & Policies \\
\hline $\begin{array}{l}\text { I mean the only thing I can think of off the top of } \\
\text { my head is that like we're certified through } \\
\text { OEFFA. }\end{array}$ & $\begin{array}{l}\text { Certified } \\
\text { Organic }\end{array}$ & Government & Policies \\
\hline $\begin{array}{l}\text { Most of what I deal with is through OEFFA } \\
\text { which is a certifying body for organic. So if } \\
\text { there's regulations and stuff, that's kind of what } \\
\text { I'm dealing with. Which is essentially no } \\
\text { sprays... }\end{array}$ & $\begin{array}{l}\text { Certified } \\
\text { Organic }\end{array}$ & Government & Policies \\
\hline $\begin{array}{l}\text { Selling organic impacts how I farm because } \\
\text { there's certain laws and regulations that I have to } \\
\text { follow in order to do that. }\end{array}$ & $\begin{array}{l}\text { Certified } \\
\text { Organic }\end{array}$ & Government & Policies \\
\hline $\begin{array}{l}\text { There are a lot of rules and a lot of just keeping a } \\
\text { written record of everything you do } \\
\text { essentially...but we record everything we plant, } \\
\text { how much, when it's transplanted, where it's } \\
\text { transplanted, like if we apply any kind of } \\
\text { amendments to the soil or any kind of [organic] } \\
\text { pesticides, or if we cultivated. }\end{array}$ & $\begin{array}{l}\text { Certified } \\
\text { Organic }\end{array}$ & Government & $\begin{array}{l}\text { Record } \\
\text { Keeping }\end{array}$ \\
\hline
\end{tabular}




\begin{tabular}{|c|c|c|c|}
\hline $\begin{array}{l}\text { And there is a paper trail for everything. Like I } \\
\text { have to write down every time I do anything. I } \\
\text { have to write it down. }\end{array}$ & $\begin{array}{l}\text { Certified } \\
\text { Organic }\end{array}$ & Government & $\begin{array}{l}\text { Record } \\
\text { Keeping }\end{array}$ \\
\hline $\begin{array}{l}\text { In order to buy and purchase chemicals and } \\
\text { fertilizers, you have to have a license. And so in } \\
\text { order to keep your license, you have to attend so } \\
\text { many hours of classes every year. And that way } \\
\text { you can purchase. If you don't have a license you } \\
\text { can't purchase it. }\end{array}$ & Conventional & Government & Policies \\
\hline $\begin{array}{l}\text { There is rules and regulations. For example, wind, } \\
\text { you know, for drift. You've got to, you've got to } \\
\text { be stringent on what time of day you should be } \\
\text { spraying and wind. To where it would drift away } \\
\text { from the area that you're spraying at. So that's a } \\
\text { regulation. And you have to keep records of what, } \\
\text { when, and where. You have to keep weather. } \\
\text { You know, the temperature that you're spraying } \\
\text { in, the humidity you're spraying in, the time of } \\
\text { day. That all has to be kept on file. When you're } \\
\text { spraying and how you're spraying. You know, } \\
\text { the pressures that you're using on the sprayer. } \\
\text { Those are all things that are guidelines that are } \\
\text { restricted. That you have to go by. }\end{array}$ & Conventional & Government & $\begin{array}{l}\text { Policies } \\
\text { Record } \\
\text { keeping }\end{array}$ \\
\hline
\end{tabular}

\section{Policies (Subtheme)}

The conventional farmers interviewed stated that there were rules and policies that they must follow in order to buy and use chemicals. The conventional farmers had to have a license to purchase the chemicals. These farmers had to attend classes each year in order to renew the license. There were also rules about when, where and how much they could spray. The farmers indicated that these policies for chemicals were enforced by the state. These were the main regulations that affected the conventional farmers' farming practices. The certified organic farmers mentioned the USDA Organic Standards, but more often discussed the local organization for organic certification called OEFFA which stands for Ohio Ecological Food and Farm Association. This organization includes farmers in multiple states in the Midwest, 
including both Ohio and Indiana. OEFFA monitored the farmers' practices to make sure they were in compliance with the organic standards, offered resources to help new certified organic farmers get started and connected certified organic farmers in this region. The farmers who were non-certified organic chose to not pay for certification because in general, they did not feel that their customers were demanding that their products be certified. These farmers could not market as "certified organic" but could say "chemical free" or "pesticide free". These farmers followed organic practices, but they did not have regulations besides food safety rules when selling their

products. All groups of farmers were affected by the buffers required between organic farms and conventional farms. Conventional farmers had to follow the rules set in place to keep chemical drift from going to other places. All certified and non-certified organic farmers stated that even if these rules were followed, chemical drift still occurred, and had damaged their crops in the past.

\section{Record Keeping (Subtheme)}

All the conventional farmers had to be certified and have a license to use chemicals on their farms. In addition to attending classes, they had to keep paperwork with detailed information about when they sprayed, how much they sprayed, and any weather conditions such as wind and rain. The conventional farmers did the record keeping, but did not believe this to be overly difficult, nor did they express frustration. It was just something that they had to do. The certified organic farmers had to keep a record of everything they did, from the seeds they bought, to when the produce was harvested, to how it was packed and sold. These records are used to make sure they are in compliance with all the organic practices. Record keeping was a common theme mentioned by the farmers whether conventional or certified organic. The certified organic 
farmers seemed to spend more time on the record keeping, which is very detailed. This record keeping was not difficult enough to prevent them from continuing with being certified organic. In fact, one certified organic farmer said, "So the detailed record keeping is probably the most challenging and time-consuming part. But is also is valuable to us as well to have that level of records.”

\section{RQ\#5: Partnering with Registered Dietitian Nutritionists}

The fifth research question was, "Have farmers considered partnering with a Registered Dietitian Nutritionist (RDN) to increase consumer awareness of health benefits of their products?" Table 6 provides example quotes from the farmers on their thoughts and ideas about working with RDNs. 
Table 6: Quotes Associated with RQ\#5

\begin{tabular}{|c|c|c|c|}
\hline $\begin{array}{l}\text { RQ\#5 Have farmers considered partnering } \\
\text { with a Registered Dietitian to increase } \\
\text { consumer awareness of health benefits of their } \\
\text { products? }\end{array}$ & $\begin{array}{l}\text { Type of } \\
\text { Farm }\end{array}$ & $\begin{array}{l}\text { Main } \\
\text { Theme(s) }\end{array}$ & Subtheme(s) \\
\hline $\begin{array}{l}\text { But like a preventative care program that like } \\
\text { involved... that involved getting local produce } \\
\text { you know making it accessible to a wider like } \\
\text { audience or people who were seeking that out if } \\
\text { they were somehow connected through the } \\
\text { dietitian. }\end{array}$ & $\begin{array}{l}\text { Non-certified } \\
\text { organic }\end{array}$ & $\begin{array}{l}\text { Working } \\
\text { with } \\
\text { RDNs }\end{array}$ & $\begin{array}{l}\text { Ideas } \\
\text { Accessibility }\end{array}$ \\
\hline $\begin{array}{l}\text { And so we're looking for additional pathways to } \\
\text { get that food to the hands of people that need it } \\
\text { and want it. And dietitians I think can play a huge } \\
\text { role in that. }\end{array}$ & $\begin{array}{l}\text { Non-certified } \\
\text { organic }\end{array}$ & $\begin{array}{l}\text { Working } \\
\text { with } \\
\text { RDNs }\end{array}$ & $\begin{array}{l}\text { Ideas } \\
\text { Accessibility }\end{array}$ \\
\hline $\begin{array}{l}\text { Like doctors instead of prescribing medication } \\
\text { would actually say well you need to like eat more } \\
\text { broccoli. Here's your prescription. Go buy } \\
\text { broccoli. You know, eat healthier. }\end{array}$ & $\begin{array}{l}\text { Non-certified } \\
\text { organic }\end{array}$ & $\begin{array}{l}\text { Working } \\
\text { with } \\
\text { RDNs }\end{array}$ & $\begin{array}{l}\text { Ideas } \\
\text { Communicati } \\
\text { on } \\
\text { Education }\end{array}$ \\
\hline $\begin{array}{l}\text { A community nonprofit food hub like that you } \\
\text { know, I think it could be a cool place to involve } \\
\text { dietitians. And it's kind of already set up to } \\
\text { connect to a bunch of people who area accessing } \\
\text { that produce anyway. }\end{array}$ & $\begin{array}{l}\text { Certified } \\
\text { Organic }\end{array}$ & $\begin{array}{l}\text { Working } \\
\text { with } \\
\text { RDNs }\end{array}$ & $\begin{array}{l}\text { Ideas } \\
\text { Community } \\
\text { outreach }\end{array}$ \\
\hline $\begin{array}{l}\text { And just the whole piece of educating people } \\
\text { about how to cook using fresh seasonal produce. } \\
\text { And then helping them to access it. }\end{array}$ & $\begin{array}{l}\text { Certified } \\
\text { Organic }\end{array}$ & $\begin{array}{l}\text { Working } \\
\text { with } \\
\text { RDNs }\end{array}$ & $\begin{array}{l}\text { Ideas } \\
\text { Education } \\
\text { Accessibility }\end{array}$ \\
\hline $\begin{array}{l}\text { So I would think talking to the dietitian would } \\
\text { give me a lot of insight into what the market is } \\
\text { actually looking for and at the same time what is } \\
\text { healthy for people. }\end{array}$ & $\begin{array}{l}\text { Certified } \\
\text { Organic }\end{array}$ & $\begin{array}{l}\text { Working } \\
\text { with } \\
\text { RDNs }\end{array}$ & $\begin{array}{l}\text { Ideas } \\
\text { Education }\end{array}$ \\
\hline $\begin{array}{l}\text {...if a dietitian has any influence with people who } \\
\text { are working on the farm bill, sure thing. Because } \\
\text { that's pretty critical to our business that it be } \\
\text { structured correctly. }\end{array}$ & Conventional & $\begin{array}{l}\text { Working } \\
\text { with } \\
\text { RDNs }\end{array}$ & $\begin{array}{l}\text { Ideas } \\
\text { Communicati } \\
\text { on }\end{array}$ \\
\hline $\begin{array}{l}\text { So the work with a dietitian and your plant } \\
\text { technologist...biologist you know, can come up } \\
\text { with the product, you know, for us to grow. }\end{array}$ & Conventional & $\begin{array}{l}\text { Working } \\
\text { with } \\
\text { RDNs }\end{array}$ & Ideas \\
\hline $\begin{array}{l}\text { You've got to start with the young. This is where } \\
\text { your big job is. And starting with the young } \\
\text { means you've got to convince the parents that } \\
\text { what you're trying to talk to them about is so } \\
\text { important. }\end{array}$ & Conventional & $\begin{array}{l}\text { Working } \\
\text { with } \\
\text { RDNs }\end{array}$ & $\begin{array}{l}\text { Ideas } \\
\text { Education }\end{array}$ \\
\hline
\end{tabular}




\section{Accessibility (Subtheme)}

The farmers who farmed organically mentioned working with RDNs to help improve access to fresh produce. Only certified and non-certified organic farmers mentioned accessibility in this study. These certified and non-certified organic farmers wanted to make local produce available to all who sought it, and wanted to make the produce affordable. These certified and non-certified organic farmers believed that working with an RDN could help connect people to the farmers markets and make sure all people in the community had access to fresh local produce. These farmers mentioned that produce should be accessible to all low and middleincome consumers in all types of areas. These farmers commented that the locations and hours of farmers markets could be limiting access for some low-income people. The consumers may not be able to come to the market on the days and times it was open, especially if the market was only open one day a week. One certified organic farmer suggested an RDN could work with a food hub to help deliver food to those not able to get to the farmers markets. The farmers that sold at farmers markets liked the vouchers that are given to people who use the food and nutrition assistance programs. Some examples of these programs are: Women, Infants and Children (WIC), Senior Farmers' Market Nutrition Program (SFMNP), and Supplemental Nutrition Assistance Program (SNAP) vegetable vouchers. The farmers who sold at the farmers markets were happy that the people on these assistance programs can use the vouchers for produce at the farmers market. Although the vouchers were available, the farmers stated that people of the community were not taking full advantage of the vouchers. 


\section{Communication (Subtheme)}

The farmers in this study mentioned that RDNs could communicate with consumers and also with the farmers themselves. One conventional farmer said RDNs could communicate with food scientists or plant biologists who know about breeding techniques of crops to increase nutrient density. This information could then be communicated with the farmers and the farmer could grow more nutrient dense crops. Some farmers stated an RDN could recommend certain types of crops to grow that consumers may be demanding. These farmers would then adjust their rotation and add these crops. Two conventional farmers mentioned their business would be affected if RDNs had input in government policies. These farmers suggested that if RDNs and farmers communicated and discussed the farmers' needs, the RDNs could then communicate this information to the people who work on policies. This would ensure that the farmers' thoughts were being heard by the policy makers. The conventional farmers thought the direct community involvement of RDNs would be more suited to smaller fruit and vegetable farmers rather than the large-scale commodity farmers. Smaller scale produce farmers were more likely to be communicating directly with the consumers.

\section{Community Outreach (Subtheme)}

The farmers in this study stated that good nutrition was important and they showed interest in sharing this information with the public. The farmers' comments were mostly focused on providing education to the people of their communities and helping the fresh produce be more accessible to those who need and want it. One certified organic farmer had suggestions about RDNs working with organizations to get grants for community projects and research. This farmer suggested RDNs work with a food hub which connects people in communities and 
provides food to people in need. All the farmers who ran a community supported agriculture (CSA) program were very focused on helping to improve the health of the community and reaching out to their members. These farmers thought they could partner with RDNs to provide additional resources in their CSA boxes and online via their Facebook pages to reach more people. Whether conventional or organic, all the farmers expressed a connection with their community and wanted to work with RDNs in some way that would affect the community around them.

\section{Education (Subtheme)}

The farmers mentioned educating people in the public about: when produce was in season, how to cook fresh produce, the importance of fresh local produce for nutrition and health, and how to incorporate more fresh produce into their diets. Farmers mentioned that it was important to teach children about farming and healthy eating and expose them to different types of produce. The farmers believed that children do not know much about farming or where food comes from. These farmers stated it was important that children learn healthy eating habits at home at a young age so it will carry on to adulthood. Farmers suggested RDNs could help educate families with children about the health benefits of fresh produce to help improve their fruit and vegetable intake. The farmers market was a place where the farmers believed this education could take place.

\section{Ideas/Examples (Subtheme)}

All farmers in this study had very interesting, specific ideas of how farmers and RDNs could work together (Table 6). One farmer using conventional methods said RDNs could 
communicate with food scientists and explore breeding techniques to increase nutrient density of the crops. The RDN could then provide them with ideas about what crops to grow that may be more nutritious or more profitable. The farmers also thought RDNs could have a say in the government policies and wanted to work together on policy formation so that the farmers' voices would be heard. The certified and non-certified organic produce farmers believed that RDNs should work directly with the farmers at farmers markets. Some of their suggestions included: working with CSA farmers by creating balanced CSA boxes, having a booth at farmers markets for nutrition education, having a booth at farmers markets with a chef to do cooking demos, working with community food hubs, working with doctors to help provide prescribed healthy diet recommendations, promoting local farmers' produce through social media accounts such as Facebook, and finding opportunities for RDNs and farmers to work together and apply for research grants through various organizations.

\section{Additional Findings}

\section{Conventional vs Organic Farming}

The data highlights the significant difference in attitudes the farmers' held related to the approaches to organic and conventional farming. Some differences in attitudes and beliefs that emerged included: Organic farms had better soil quality and more beneficial insects in the soil; Organic farms had a higher loss of products compared to conventional farms; Organic farmers were concerned about drift of chemicals from conventional farms. Many farmers in all groups of this study commented that conventional farming seemed to be more popular and more supported in this area of the country because of the convenience and availability of places to sell the products. One certified organic farmer said, "because at least where we're at, there is a shortage 
of chemical free locally grown produce." The conventional farmers commented how easy it was to go to the local grain elevator to deliver their products, thus reducing costs in time. There were many elevators around Indiana and Ohio that accepted corn and soybeans; therefore, sale of commodity products was relatively easy. Because of the conventional farming all around, it was difficult for certified organic farmers to begin because they must grow for 3 years on soil with no chemicals before they could be certified. One conventional farmer said, “...Occasionally I look into organics and stuff. But to become a certified organic, there's a lot of legwork to do. And working a full-time job that's a lot of attention has to be put into your field." A certified organic farmer even said that organic farming was not widely accepted in this area. Although it may be difficult to become certified organic, the farmers who choose to be certified organic felt that they could get some good support through organizations such as OEFFA. These certified organic farmers believed that certification was a great way to improve organic practices because any research or grants were only provided to those who were certified. One certified organic farmer made it very clear about the benefits of being certified organic:

So number one I think the biggest reason to certify for me would be the fact that...when you certify your farm as organic, it's...in a way you're kind of giving a vote. You're telling the USDA like okay, here's an organic farm.

Most farmers throughout all groups of this study agreed that not everyone needed to farm organically and not everyone needed to farm conventionally. It takes both types of farming to provide enough food for everyone in the world. In fact, one certified organic farmer said:

I do farm organically, but I also understand that there's a lot of people in this world to feed and not everybody can farm organically. Because we want to produce enough. We 
don't produce enough now they say, right? So for everybody to farm that way, probably wouldn't be able to feed everybody."

\section{Sense of Community}

The farmers in this study talked about community in a few different ways. The farmers themselves had a community where they gathered together and helped each other with problem solving and learning new ways to practice their farming methods. They formed bonds with each other at farmers markets or just through living close to other farmers. These farmers also had a strong sense of community with the neighborhoods or areas where they were growing and/or selling their products. The farmers mentioned they wanted to educate the community members about farming and healthy eating. One place where the sense of community was evident was at farmers markets. At farmers markets, the farmers in this study connected with the other farmers by sharing ideas and suggestions for farming techniques. The farmers also connected with the customers at farmers markets when they saw the same people each week and talked with the customers about the products. The farmers had a lot to say about their sense of community. One non-certified organic farmer stated:

I mean to feel a part of a vibrant local community, and I think at the farmers market it's the same idea. It's a real sense of community, and the sense of communication with people who grow your food, that's healthy. That's feeling involved. That's feeling like you're a part of something alive and well. I think. So yeah there's a lot of benefits. 
Another non-certified organic farmer stated:

And the fact that it seems to be more of a community. The same... A lot of the same customers come back year after year and they'll bring their friends or whatever or other family members. And the community involvement around fresh produce, fresh vegetables... you know, is always constantly going and getting bigger or smaller, getting bigger and smaller. But it always seems to involve conversations.

Not only did farmers have a community with other farmers, but they felt that they had a bond of community with their customers and the public where they lived. This was important to the farmers because it motivated them to provide good quality products and gave them resources for networking. One non-certified organic farmer even said: "I enjoy doing it and I enjoy selling vegetables. It's a joy and a pleasure to see smiles on people's faces. That's the reason why I do it". When asked about how people could learn about farming and where food comes from, every farmer's response was that they should go talk to local farmers. The farmers stated they would welcome people to their farm to look around and learn. The farmers also stated they would talk to customers about farming and their farming practices at farmers markets. These farmers were very open and wanted to share their knowledge with the community around them.

\section{Continuing Education for Farmers}

Farmers were very interested in learning about improving their farming methods and keeping up with current research findings in the farming world. They read books, went to seminars, read articles, and talked to other farmers in order to learn and stay abreast of changes and current trends. The conventional farmers that attended classes to get their license for 
chemical use reported that these classes were interesting and informative. Some of the government and state agencies had educational programs through universities to help teach farmers about different aspects of farming practices. One certified organic farmer discussed how they have a support system:

...So the Ohio Ecological Food and Farm Association, they connect... well they're like a farm...a sustainable farm advocacy type group. So they do farm tours. And they have a big conference every winter. And they have a begin farming mentorship.

The farmers also liked to share their knowledge with other farmers and customers. Many of the farmers liked the continuing education component that is a part of the farming profession because learning keeps them engaged and makes farming interesting.

\section{Summary}

Five emergent themes: economics, environment, government, health/nutrition, and working with RDNs were identified from 24 face-to-face interviews. Within each of these topics further subthemes were also determined. Conventional farmers were more influenced by economics such as time, money and business outcomes when choosing their farming methods. Both certified and non-certified organic farmers were more influenced by health/nutrition and the environment when choosing their farming methods. Every farmer interviewed reported a connection with the environment in some way. Farmers considered the environment when making decisions about chemicals, weed control, soil health, and the waterways on/near their properties. Conventional farmers completed record keeping for spraying their chemicals while certified organic farmers completed record keeping to trace their products from seed to 
harvesting to selling. All farmers showed interest in working with RDNs and had ideas that focused on education, accessibility and community outreach. 


\section{CHAPTER 5}

\section{DISCUSSION}

The purpose of this qualitative study was to explore the attitudes and factors that motivated farmers from Indiana and Ohio to operate either a certified organic, a non-certified organic, or a conventional farm, and to explore the interest of farmers in partnering with Registered Dietitian Nutritionists (RDNs) in educating consumers about the health benefits of eating fruit and vegetables to increase daily consumption. This chapter contains a discussion of the results from this study.

\section{Demographics}

\section{Comparison to National Averages}

In the current study, purposeful sampling was used to gather 24 farmers with equal distribution of 8 farmers of each farming type (conventional, certified organic, non-certified organic). The subjects in this study were diverse. There was a large age range between 28 to 80 years with a mean age of 49 years \pm 15 years. According to the 2017 Census of Agriculture (CoA), the average age of national farm producers was 57.5 years (2017 Census of Agriculture, 2019). The average age of farmers in the current study was 8.5 years less than the national average. This difference could be due to the wide age range in the current study and the farmers' 
varied farming experiences. This was illustrated by the number of years that the farmers had been farming. In general, the older the farmer, the longer the farmer had been operating their farm. There were a few outliers, however. Two farmers over 40 years old had only been operating their farm for less than 10 years. The majority (67\%) of farmers in the current study were lifelong farmers who had been helping on their family farm since they were children. According to the $2017 \mathrm{CoA}$, national farm producers had been farming for an average of 21.3 years (2017 Census of Agriculture, 2019). The average number of years that farmers in the current study had been farming was 21.2 years, which closely matched the CoA's average. The $2017 \mathrm{CoA}$ reports that of the national farm producers, 64\% were men and $36 \%$ were women. There were 18 men (75\%) and six women (25\%) in the current study. Only one woman farmed conventionally, the other five women farmed organically. The 2017 CoA also shows that for $42 \%$ of national farm producers, farming is the primary occupation. There are $58 \%$ of national farm producers that have another occupation in addition to farming. In the current study, $54.2 \%$ of the subjects farmed for their primary occupation and $45.8 \%$ of the subjects had a secondary job besides farming. This may be attributable to farmers having other interests or the need for extra income if the farm cannot sustain the farmer financially. Table 7 shows the demographics of the current study compared to the national demographics. 
Table 7: Demographics of Current Study versus National Average

\begin{tabular}{|l|c|c|}
\hline & $\begin{array}{c}\text { CURRENT STUDY } \\
\text { AVERAGE }\end{array}$ & $\begin{array}{c}\text { NATIONAL } \\
\text { AVERAGE }\end{array}$ \\
\hline Age & 49 years & 57.5 years \\
\hline How long they have farmed & 21.2 years & 21.3 years \\
\hline Men & $75 \%$ & $64 \%$ \\
\hline Women & $25 \%$ & $36 \%$ \\
\hline Primary Occupation & $54.2 \%$ & $42 \%$ \\
\hline $\begin{array}{l}\text { Have a secondary } \\
\text { Occupation }\end{array}$ & $45.8 \%$ & $58 \%$ \\
\hline
\end{tabular}

It was also common for the gross sales to increase as the number of acres farmed increased. One exception to this was a small conventional fruit and vegetable farm with less than 50 acres that had a gross income between $\$ 500,000$ and $\$ 999,999$. This example shows that even if farms are small, they can still be a viable business. The comparison of the demographics for farmers in the current study to the demographics of the national farm producers shows that the current study was a close representation of the national farm producers.

\section{Non-Certified Organic Farms}

For the purposes of this study, the term non-certified organic was defined as farmers that used organic methods, but did not submit paperwork to the USDA to become certified. According to the USDA, farmers who sell less than $\$ 5,000$ per year in organic sales do not have to be certified (USDA Do I need to be Certified Organic? 2018). Even though these farmers are "exempt" from the certification, they can still apply for voluntary certification (USDA Do I need to be Certified Organic? 2018). The farmers interviewed for this study did not fall into this 
category defined by the USDA. The non-certified organic farmers in this study were not using the "organic" label when marketing their products, but instead marketed as "pesticide free", "chemical free" or "naturally grown".

\section{Economics}

\section{Consumer Demand for Organic Products}

Despite the higher costs, health-conscious consumers demand organic foods at an increasingly high rate (Meyer, 2017; USDA Economic Research Service, 2017). According to the USDA Census of Agriculture, in 2015, the top 10 states with the highest sales in organic foods included: California, Washington, Pennsylvania, Oregon, Wisconsin, Texas, New York, Colorado, Michigan, and Iowa (Chow, 2015). The sales for organic foods in California totaled \$2.2 billion. These 10 states made up $78 \%$ of the total U.S. organic food sales in 2014 (Chow, 2015). Sales of organic foods continue to rise each year in all states, showing that more people are seeking organic foods (Chow, 2015). Since the demand for organic foods is increasing, there should be more farmers producing organic products. However, according to the USDA, less than $1 \%$ of US farmland is registered as certified organic (USDA Certified Organic Survey, 2016).

In 2020, Michelob Ultra Pure Gold, which is Anheuser-Busch's first USDA certified organic beer, premiered a Super Bowl commercial geared towards organic farmers (Alcántara, 2020). The commercial highlighted their new program called 6-for-6 Pack. This program helps farmers transition six square feet of farmland into an organic pasture. It works by taking a portion of the proceeds from each six-pack of Michelob Ultra Pure Gold that is sold and appropriating the funds directly to the farmers to help with the transition to organic farming 
(Alcántara, 2020). The fact that this program was put on a Super Bowl commercial indicates that this company is trying to make the public more aware of the low number of organic farms. The company is not only spreading awareness, but they have created a program to make changes.

There are many factors that affect the decisions of farmers when exploring whether to become certified organic. According to Modern Farmer (2018), there are five reasons why it is difficult to obtain organic certification: the transition takes three years, certification is not free, the rules can be vague, the paperwork can be a burden, and neighbors with conventional farms may not be friendly. Any of these reasons could be why many farmers choose not to farm organically and opt for conventional methods. In the current study, the most common reasons the farmers chose to not be certified organic were the high cost of certification and the lack of consumer demand in their area. The farmers reported that the consumers wanted organic products, but did not seem to mind if the products were certified organic. One non-certified organic farmer stated, "We were certified and we decided to drop... not pay for the certification every year just because it is a pretty large expense and our clients didn't really care either way if it was certified or just grown organically."

\section{Business versus Health/Nutrition and Environment}

The current study explored the factors that affected how farmers made decisions. Running the business of a farm is always a factor that farmers must consider. The data from this study showed that conventional farmers mentioned running the business more often than organic farmers. Certified and non-certified organic farmers also discussed their business plans and marketing, but these organic farmers commented more often about providing chemical free produce to the community and protecting the environment by not using chemicals. Although the 
conventional farmers did believe that good nutrition is important for overall consumer health, they continued to use chemicals. The main concern for these farmers was the financial stability of their businesses. Conventional farmers did not see organic farming methods as an alternative due to the high costs associated with an increased time commitment. Increased time commitments meant more labor costs and decreased efficiency. The farmers felt that they had to use the chemicals to keep yields high in order to keep their business running. To these

conventional farmers, cost and time were more valued than the potential negative health impacts of chemicals. In a study done by Thompson, A. W., Reimer, A., \& Prokopy, L. S. (2015), the researchers found that farmers who had higher stewardship or positive environmental attitudes were more likely to support sustainable agriculture and more environmentally friendly practices. This statement is reflected in the current study as all of the organic farmers were focused on the environment and health while the conventional farmers were more focused on business costs.

\section{Attitudes and Beliefs Related to Farming Methods}

Although organic farming is becoming more popular, the statistics indicate that the majority of farms in Ohio and Indiana use conventional methods. In fact, only $0.74 \%$ of the farms in Indiana and $0.78 \%$ of the farms in Ohio are certified organic (USDA Certified Organic Survey, 2016; USDA Agriculture Review, 2017). The farmers in the current study commented that there are not as many organic farms in this area, and conventional farming seems to be more common. The conventional farmers talked about how convenient it is to get their crops to the grain elevators to sell. The farmers in the current study mentioned that it is sometimes difficult to begin as a certified organic farmer because there is a three-year waiting period or transition 
period for the ground to be free from chemicals before the products can be sold as certified organic. This barrier could be a reason why conventional farming is more common.

\section{Government}

Another factor that affects whether farmers use conventional or organic methods could be the role of the government in farming policy oversight. There are USDA government programs which provide financial support to farmers through subsidies, insurance and payments for implementing conservation practices (U.S. Government Accountability Office, 2020).

Surprisingly, a few conventional farmers mentioned that the government subsidies were not the best thing for farmers. These farmers believed that although the subsidies may help the farmer in the short term, it may be better to get rid of this program in the long term. The farmers may believe this because some farmers can get paid for their crops even if they do not plant due to weather. Although this is good in the short term, it is not good for the farmer or the land in the long term if they do not plant their crops. While these few conventional farmers thought that the government should not be as involved with farming, there were some certified and non-certified organic farmers in this study who thought the government should provide more funding to local organic farmers. These farmers may believe this because the main focus of the government seems to be on commodity large scale farmers, which are currently a majority. If more government funding was used for local organic farms, organic farming could potential expand and more farmland could be converted to organic.

The certified organic farmers mentioned the USDA Organic Standards, but more often affiliated with the local organization for organic certification called the Ohio Ecological Food and Farm Association (OEFFA). One certified organic farmer stated, "Most of what I deal with 
is through OEFFA which is a certifying body for organic. So if there's regulations and stuff, that's kind of what I'm dealing with. Which is essentially no sprays..." Farmers from both Indiana and Ohio were part of this organization, and they seemed more involved and received greater benefit from OEFFA rather than the USDA. Those farmers who were certified organic said that it was important to show the government that there were organic farmers because each one counted as far as research and grant money opportunities. One certified organic farmer stated:

So number one I think the biggest reason to certify for me would be the fact that...or I've heard it described like this to me is... when you certify your farm as organic it's... in a way you're kind of giving a vote. You're telling the USDA like okay here's an organic farm. And so when the USDA decides where they're going to put their attention, their funding, grants and that kind of stuff, the more farmers... or research... the more farmers who are certified organic send the message to the USDA that like hey we need... We have farmers doing this.

\section{Environment}

\section{Conventional versus Organic}

The literature indicates farmers who farm with organic methods had a higher appreciation for the environment than farmers who used conventional farming techniques (Darekar \& Naik, 2017; Thompson, Reimer, \& Prokopy, 2015; Welsh \& Rivers, 2011). In contrast to this research, all farmers in the current study, whether organic or conventional, were concerned about the environment. These farmers all mentioned that the environment played a role in their decisions, especially protecting the waterways from pollution, preventing erosion and promoting soil health. The certified and non-certified organic farmers chose to not use synthetic chemicals. 
The conventional farmers used synthetic chemicals, but were cognizant of the environmental impacts of their decision. These farmers attempted to limit chemical use while practicing safe methods.

Biodiversity was one aspect that certified and non-certified organic farmers in this study expressed more often than conventional farmers. The organic farmers in the current study were very proud of having biodiversity on their property and thought it was important for the environment. In a study done by Kross et al. (2018), the researchers surveyed organic and conventional farmers about their views on three different types of wildlife. The researchers found that the organic farmers viewed all three types of wildlife more positively than the conventional farmers. The certified and non-certified organic farmers in the current study mentioned the topic of biodiversity, animals and wildlife more often than conventional farmers. The certified and non-certified organic farmers appreciated the diversity of wildlife and could see the positive impact the wildlife could have on the environment.

\section{Chemical Drift}

The United States Environmental Protection Agency (EPA) reports that drift of herbicides can injure some crops (EPA Introduction to Pesticide Drift, 2020). Drift from herbicides and pesticides can make crops unsellable if they end up in certified organic farms (EPA Introduction to Pesticide Drift, 2020). In the current study, certified and non-certified organic farmers were concerned about chemical drift from conventional farms. Although the conventional farmers attempted to follow the recommendations and regulations for spraying, drift still occurred. The certified and non-certified organic farmers in this study reported drift from conventional farms had killed their products and affected their land. The EPA reports that 
state and local agencies receive thousands of complaints each year regarding drift of pesticides.

These agencies spend time and resources to investigate all of these drift complaints (EPA Introduction to Pesticide Drift, 2020). The certified and non-certified organic farmers in the current study attempted to talk to their neighbors about the issue up front but, unfortunately, the problem still occurred. All the farmers wanted to get along with their neighbors and work together in harmony. According to the organic farmers, this is not always easy to accomplish. In fact, one non-certified organic farmer said:

And I talk with them and I'm trying to figure out how can we work together and not fight against one another. I don't want to hate you. I want to respect you. And I want you to respect me. But it becomes very frustrating when you see them literally kill your plants that you put everything into it as well. So that's my... that's my biggest hurdle I will say.

"And it's like how do you...you have to figure out how to work... find a symbiotic relationship between you and the commercial farmers. And that's something that we really need to start bridging better."

\section{Health/Nutrition}

The literature indicates there was not consistent or overwhelming evidence that organic foods were more nutritious than conventionally produced foods (Smith-Spangler et al., 2012). Prior research also explored the nutrient density of organic versus conventionally grown foods. The general consensus from multiple researchers was that there is insufficient evidence to say that organic foods have a higher nutrient content than conventionally produced food (Nakamura et al., 2007; Pérez-López et al., 2007; Mie et al., 2017; Søltoft et al., 2011; Johansson, et al., 20141; Amodio et al., 2007; Cardoso, Tomazini, Stringheta, Ribeiro, \& Pinheiro-Sant'Ana, 
2011). The farmers interviewed in the current study tested their soils, and certified and noncertified organic farmers believed that there were more nutrients in their soil than in conventionally farmed soil. The farmers were very conscious of nutrient content of their soil, specifically nitrogen and carbon. They grew certain crops in a specific order at specific times to make sure the nutrient content of their soil is the best that it can be. Many of the farmers sent soil samples for testing, and also sample products for nutrient analysis. The certified and noncertified organic farmers interviewed believed that they were promoting health because their products had more nutrition than conventional products.

Prior research also examined chemical contaminant levels of organic versus conventionally grown foods. Researchers did find that conventional produce had a 30\% higher risk for pesticide contamination compared to organic produce (Smith-Spangler et al., 2012). The certified and non-certified organic farmers of this study did not use pesticides because they did not want to sell products with chemicals to their customers. Conversely, conventional farmers believed that they were positively affecting the health of the public because they were supplying food on a large scale. One conventional farmer said:

“I feel like if I didn't farm and raise crops, [the public] wouldn't have anything to eat. I mean I feel like I'm doing a service by selling food. Other than that, I don't know that it affects other people, you know, how I farm affects people's lives."

All farmers interviewed believed that the people in Indiana and Ohio were not eating enough fruit and vegetables. The farmers seemed to think people were disconnected with where their food was coming from because so much food today is processed. The farmers felt that the public may be more inclined to eat locally and know what foods are in season in our area if 
education was provided about farming methods and how to use the fresh produce. Educating the public was more often mentioned by certified and non-certified organic farmers, likely because they interface with the public more directly at farmers markets or with community supported agriculture than some of the conventional farmers who sell directly to commodity processors.

\section{Working with Registered Dietitians Nutritionists}

The farmers in this study were receptive to working with RDNs. They provided many interesting ideas and suggestions about how farmers and RDNs could partner together to increase the public's intake of fruit and vegetables and improve the health of their communities. The farmers all seemed willing to work with RDNs and thought that education about farming and the importance of health were important aspects. Certified and non-certified organic farmers in the current study believed that RDNs could help with accessibility of fresh produce. These farmers believed it was important for people in the public to understand the importance of eating locally and eating in season.

The Academy of Nutrition and Dietetics (The Academy) released recommendations for RDNs because they recognized the potential role RDNs could play in promoting sustainability and improving health outcomes globally (Vogliano, Steiber, \& Brown, 2015). The Academy is urging RDNs to be more involved with agriculture and promote sustainability as well as accessibility of nutrient dense foods. The Academy suggests that the world must grow the right amounts and types of food, while respecting the environment and our natural resources.

Currently there is a gap in this objective, and this is where RDNs could help lead this movement (Vogliano, Steiber, \& Brown, 2015). The Academy has written four actions that RDNs should focus on to help advance nutrition security and improve health outcomes globally: fostering 
collaboration; educating the public and health professionals; identifying outcome standards; and advocating for global nutrition security (Vogliano, Steiber, \& Brown, 2015). These goals are centered on agriculture, nutrition and health. The suggestions from the Academy include: promoting agriculture innovation and sustainable farming techniques; advocating for safe, nutritious, and efficient food processing, packaging, storage, and transportation; collaborating with retailers to increase access of nutrient-dense foods and encourage healthy options; and educating consumers on evidence-based nutrition information to facilitate adoption of healthy eating behaviors (Vogliano, Steiber, \& Brown, 2015). Accessibility of nutrient dense food was another area explored by the Academy. People who do not have access to nutrient dense foods are at risk for malnutrition and chronic diseases. The Academy believes that the world produces enough food, but the problem of inaccessibility is due to poor distribution and affordability. The Academy is urging RDNs to become involved with the agriculture system to improve the health of communities. The Academy recommends RDNs encourage and promote sustainable agriculture and provide education to the public and other professionals about food accessibility. RDNs can partner with farmers to help find ways to encourage consumers to increase their intake of nutrient dense foods such as fruits and vegetables.

Taking the recommendations from the Academy into account, the current research shows that farmers and RDNs have goals that are aligned. The outcomes from this study indicate farmers want to give consumers access to their products and provide education about farming and health. The farmers were also concerned about barriers to accessibility of their products. The Academy is encouraging RDNs to focus on education and accessibility of produce. The ideas provided by the farmers in these interviews (see Table 6) could be used to form partnerships and build programs where RDNs and farmers work together. These partnerships 
could provide education to the public about the importance of farming and the importance of a healthy diet to promote good nutrition. Many of these farmers provided ideas on how to potentially improve accessibility of produce to the public which could in turn reduce malnutrition and chronic disease rates in our communities.

\section{Summary}

Statistics indicate that there are more conventional farms than organic farms in Indiana and Ohio. The farmers in this study indicated that conventional farming seems more supported in this area by consumers and the federal government. Government subsidies were discussed, and currently, price supports benefit conventional farmers, but there were suggestions that more government assistance should be given to organic farmers. Drifting of chemicals being sprayed by conventional farmers can affect the crops of organic farms nearby, making their produce ineligible for sale. The farmers interviewed wanted to work together with other farmers even if they have different farming methods, but it is not always easy to do. The demand for organic products is still growing. More companies are advertising that there is consumer demand, and the companies are willing to invest and promote organic farming. There are programs, such as the Anheuser-Busch's 6-for-6 Pack program, that are trying to help convert conventional farmland to organic farmland. Organic farmers believed that their soil and products have more nutrients than conventionally produced products. They did soil testing to make sure their soil had the right mineral content. All farmers in this study believed the environment to be an important factor in their farming decisions. This was contradictory to previous research findings, which indicated organic farmers had a higher appreciation for the environment. The Academy is urging RDNs to be more involved with agriculture and promote sustainability as well as 
accessibility of nutrient dense foods. The ideas and suggestions gathered from farmers in the current study could be used to initiate partnerships with RNDs. Together, farmers and RDNs could build programs to help promote health in communities which could lead to the reduction of malnutrition and chronic diseases. 


\section{CHAPTER 6}

\section{CONCLUSIONS, LIMITATIONS, AND RECOMMENDATIONS}

The purpose of this qualitative study was to explore the attitudes and factors that motivated farmers from Indiana and Ohio to operate either a certified organic, a non-certified organic, or a conventional farm, and to explore the interest of farmers in partnering with Registered Dietitian Nutritionists (RDNs) in educating consumers about the health benefits of eating fruit and vegetables to increase daily consumption. This chapter presents the conclusions, identifies the study's strengths and limitations, and discusses future recommendations.

\section{Conclusions}

Five emergent themes: economics, environment, government, health/nutrition, and working with RDNs were identified after analyzing the data. Within each of these topics further subthemes were also determined. Within the theme of economics, the subthemes included: cost effectiveness, customer demand, equipment, future plans, labor, marketing, and time. Within the environment theme, the subthemes included: biodiversity, chemicals, cover crops, soil health, stewardship, weather, and weeds. The subthemes for government included: policies and record keeping. The subthemes for health and nutrition included: education, fruit and vegetable consumption, and quality of products. The subthemes for working with dietitians included: accessibility, communication, community outreach, education, and ideas/examples. 
Conventional farmers were more influenced by economic issues such as time, cost-effectiveness and running the business when choosing their farming methods. Both certified and non-certified organic farmers were more influenced by health/nutrition and the environment when choosing their farming methods. Every farmer interviewed, however, did consider the environment when making decisions about chemicals, weed control, soil health, and the waterways on/near their properties. Every farmer believed they affected the health of the public either directly or indirectly, and they all strived to produce high quality products. All farmers showed an interest in working with RDNs and had ideas that focused on education, accessibility and community outreach.

The demand for organic products is still growing. There are programs that are trying to help convert conventional farmland to organic farmland. The Academy of Nutrition and Dietetics is urging RDNs to be more involved with agriculture and promote sustainability as well as accessibility of nutrient dense foods. The ideas and suggestions gathered from farmers in the current study could be the beginning of partnerships and programs to help promote health in communities and reduce cases of malnutrition and chronic diseases.

\section{Strengths and Limitations of the Study}

This study had many strengths. There were 24 farmers interviewed and it was evenly divided among the three farming methods, with eight farmers in each group. The demographics of these farmers was varied, with a wide range of ages, number of acres farmed, and gross sales. There was a mixture of farmers from Indiana and Ohio. Male and female farmers were represented as well. There were farmers who farmed for their primary job and farmers who had a secondary job. The fact that this study was a qualitative study provided a more in-depth 
analysis into the thoughts and beliefs of the farmers. The interview questions encouraged the farmers to reflect on their beliefs and attitudes related to their farming practices, the role of the government in farming, and working with RDNs. The semi-structured, open-ended questions offered the farmers the opportunity to provide their opinions and thoughts on a range of topics related to farming methods and working with RDNs. The primary researcher was able to clarify vague answers that a survey is unable to tease out.

A limitation of this study was that it only involved farmers from a small region of Indiana and Ohio. Farmers in other areas of the country may have different opinions regarding their farming methods and working with RDNs. The assumption was made that all subjects understood the meaning of the questions and answered the questions honestly. The interviews took place after a significant weather event, flooding of farmland, and as indicated in the farmers' responses, weather was mentioned often. Had a period of weather-related prosperity occurred in years prior to the study, answers may have differed. However, the outcomes of this study align with prior research findings.

\section{Future Recommendations}

The current study shows that farmers are interested and willing to work with RDNs. These farmers had ideas and suggestions of how this partnership could work. Next, RDNs and farmers need to connect and make these partnerships happen. This could be as simple as an RDN going to a farmers market and working at a booth with a farmer to provide education to consumers. Farmers and RDNs could partner on a social media account to promote farmers' products and provide nutrition education at the same time. Farmers and RDNs could form a kind of service to make sure produce is accessible to everyone in a community, and seek out food 
hubs as a means to distribution. Further research could be done on a larger scale to determine how other farmers in various areas of the country view working with RDNs. This could provide additional partnership ideas. Some farmers have a second job as the farm may not sustain them financially. Future research could be done to investigate how to assist farmers with their business plans so the farm could fully sustain them financially if desired. Communication between farmers and RDNs is essential. With more communication, farmers and RDNs could explore additional opportunities to partner together to improve the health of communities and provide fresh local produce and education.

\section{Summary}

Research investigating farmers' beliefs and attitudes about farming methods and nutrition is limited. The current study showed that farmers are interested in nutrition and are willing to work with RDNs to improve the health of their communities through education and product accessibility. The farmers in this study have provided ideas and suggestions of how to develop a partnership between farmers and RDNs. It is important to continue talking with farmers and going forward with some of these ideas. Together, farmers and RDNs have the ability to provide education and provide access to fresh local produce and make a positive difference in the health of their communities. 


\section{REFERENCES}

2017 Census of Agriculture. (2019). Farm Producers. Retrieved from:

https://www.nass.usda.gov/Publications/Highlights/2019/2017Census_Farm_Producers. pdf. Accessed on February 24, 2020.

Alcántara, A. (2020). Michelob Ultra Pure Gold Returns to the Super Bowl with a Message for Farmers: The organic brand ditches celebrities for this year's spot. Adweek. Retrieved from: https://www.adweek.com/brand-marketing/michelob-ultra-pure-gold-returns-tothe-super-bowl-with-a-message-for-farmers/. Accessed on February 16, 2020.

Amodio, M. L., Colelli, G., Hasey, J. K., \& Kader, A. A. (2007). A comparative study of composition and postharvest performance of organically and conventionally grown kiwifruits. Journal of the Science of Food and Agriculture, 87(7), 1228-1236.

Bradbury, K. E., Balkwill, A., Spencer, E. A., Roddam, A. W., Reeves, G. K., Green, J., ... \& Beral, V. (2014). Organic food consumption and the incidence of cancer in a large prospective study of women in the United Kingdom. British Journal of Cancer, 110(9), 2321.

Çabuk, S., Tanrikulu, C., \& Gelibolu, L. (2014). Understanding organic food consumption: Attitude as a mediator. International Journal of Consumer Studies, 38(4), 337-345.

Cardoso, P. C., Tomazini, A. P. B., Stringheta, P. C., Ribeiro, S. M., \& Pinheiro-Sant'Ana, H. M. (2011). Vitamin $\mathrm{C}$ and carotenoids in organic and conventional fruits grown in Brazil. Food Chemistry, 126(2), 411-416.

Chow, Lorraine. (2015). These 10 States Account for a Whopping $78 \%$ in Sales of Organic Food. EcoWatch. Retrieved from: https://www.ecowatch.com/black-rhino-populationin-africa-2645549706.html. Accessed on March 20, 2020.

Dahm, M. J., Samonte, A., \& Shows, A. (2009). Organic foods: Do eco-friendly attitudes predict eco-friendly behaviors? Journal of American College Health, 58(3), 195-202.

Darekar, D., \& Naik, D. (2017). A study of environmental attitude between professional organic men farmers and conventional men farmers. Indian Journal of Health and Wellbeing, $8(7), 680-682$.

Dash, M., Samantaray, A., \& Dash, M. (2014). Consumer's Perception towards Organic Food Products. International Journal of Engineering and Management Research (IJEMR), 4(3), 110-113.

Electronic Code of Federal Regulations. (2018). Part 205- National Organic Program, Retrieved from: https://www.ecfr.gov/cgibin/retrieveECFR? $\mathrm{g}=\& \mathrm{SID}=\mathrm{fd} 245 \mathrm{df} 244640 \mathrm{c} 27476532673720493 \mathrm{~b} \& \mathrm{mc}=$ true $\& \mathrm{n}=\mathrm{pt} 7$. 3.205\&r=PART\&ty=HTML\#se7.3.205_1310. Accessed on December 7, 2018. 
Food and Agriculture Organization of United Nations. (2018). Organic Agriculture. Retrieved from: http://www.fao.org/organicag/oa-faq/oa-faq6/en/. Accessed on October 8, 2018.

Glaser, B. G. (1965). The constant comparative method of qualitative analysis. Social problems, 12(4), 436-445.

Grover, S., \& Gruver, J. (2017). 'Slow to change': Farmers' perceptions of place-based barriers to sustainable agriculture. Renewable Agriculture and Food Systems, 32(6), 511-523.

International Federation of Organic Agriculture Movement. (2018). Organic basics. Frequently asked questions on organics. Retrieved from: https://www.ifoam.bio/en/ourlibrary/organic-basics\#environmental\%20benefits. Accessed on October 8, 2018.

Johansson, E., Hussain, A., Kuktaite, R., Andersson, S. C., \& Olsson, M. E. (2014). Contribution of organically grown crops to human health. International Journal of Environmental Research and Public Health, 11(4), 3870-3893.

Koutsoukos, M., \& Iakovidou, O. (2013). Factors motivating farmers to adopt different agrifood systems: A case study of two rural communities in Greece. Rural Society, 23(1), 32-45.

Kross, S. M., Ingram, K. P., Long, R. F., \& Niles, M. T. (2018). Farmer perceptions and behaviors related to wildlife and On-Farm conservation actions. Conservation Letters, 11(1),

Lincoln, N. K., \& Ardoin, N. M. (2016). Cultivating values: Environmental values and sense of place as correlates of sustainable agricultural practices. Agriculture and Human Values, 33(2), 389-401.

Lu, C., Barr, D. B., Pearson, M. A., \& Waller, L. A. (2008). Dietary intake and its contribution to longitudinal organophosphorus pesticide exposure in Urban/Suburban children. Environmental Health Perspectives, 116(4), 537-542.

Michaelidou, N., \& Hassan, L. (2008). The role of health consciousness, food safety concern and ethical identity on attitudes and intentions towards organic food. International journal of consumer studies., 32(2), 163-170.

Mie, A., Andersen, H. R., Gunnarsson, S., Kahl, J., Kesse-Guyot, E., Rembiałkowska, E., ... Grandjean, P. (2017). Human health implications of organic food and organic agriculture: a comprehensive review. Environmental Health: A Global Access Science Source, 16(1), 111.

Meyer, Z. (2017). Organic food is pricier, but shoppers crave it. USA Today. Retrieved from https://www.usatoday.com/story/money/2017/07/27/organics-popularity-higher-thanever-43-billion-2016/500129001/ 
Modern Farmer. (2018). 5 Reasons Getting USDA Organic Certification Is Really Difficult. Retrieved from: https://modernfarmer.com/2018/05/5-reasons-getting-usda-organiccertification-is-really-difficult/. Accessed on February 25, 2020.

Nakamura, Y. N., Fujita, M., Nakamura, Y., \& Gotoh, T. (2007). Comparison of nutritional composition and histological changes of the soybean seeds cultivated by conventional and organic farming systems after long-term storage-Preliminary study. Journal of the Faculty of Agriculture, Kyushu University, 52(1), 1-10.

Pérez-López, A. J., López-Nicolás, J. M., \& Carbonell-Barrachina, A. A. (2007). Effects of organic farming on minerals contents and aroma composition of Clemenules mandarin juice. European Food Research and Technology, 225(2), 255-260.

Raab, C., \& Grobe, D. (2005). Consumer knowledge and perception about organic food. Extension Journal, 43(4).

Reimer, A. P., Thompson, A. W., \& Prokopy, L. S. (2012). The multi-dimensional nature of environmental attitudes among farmers in Indiana: Implications for conservation adoption. Agriculture and Human Values, 29(1), 29-40.

Selfa, T., \& Qazi, J. (2005). Place, taste, or face-to-face? Understanding producer-consumer networks in "local" food systems in Washington State. Agriculture and Human Values, 22(4), 451.

Smith-Spangler, C., Brandeau, M. L., Hunter, G. E., Bavinger, J. C., Pearson, M., Eschbach, P. J., ... Bravata, D. M. (2012). Are organic foods safer or healthier than conventional alternatives?: A systematic review. Annals of Internal Medicine, 157(5), 348-366.

Søltoft, M., Bysted, A., Madsen, K. H., Mark, A. B., Bügel, S. G., Nielsen, J., \& Knuthsen, P. (2011). Effects of organic and conventional growth systems on the content of carotenoids in carrot roots, and on intake and plasma status of carotenoids in humans. Journal of the Science of Food and Agriculture, 91(4), 767-775.

Thompson, A. W., Reimer, A., \& Prokopy, L. S. (2015). Farmers' views of the environment: The influence of competing attitude frames on landscape conservation efforts. Agriculture and Human Values, 32(3), 385-399.

United States Department of Agriculture. (2016). Certified Organic Survey. National Agricultural Statistics Service. Retrieved from: http://usda.mannlib.cornell.edu/usda/current/OrganicProduction/OrganicProduction-0920-2017_correction.pdf. Accessed on October 8, 2018.

United States Department of Agriculture. (2017). State Agriculture Overview. Data from Quick Stats. Retrieved from: https://www.nass.usda.gov/Quick_Stats/Ag_Overview/stateOverview.php?state=OHIO and 
https://www.nass.usda.gov/Quick_Stats/Ag_Overview/stateOverview.php?state=indiana. Accessed on October 8, 2018.

United States Department of Agriculture. Organic Food Production Act of 1990. (2005).

Retrieved from:

https://www.ams.usda.gov/sites/default/files/media/Organic\%20Foods\%20Production\%2 0Act\%20of\%201990\%20(OFPA).pdf. Accessed on October 21, 2018.

United States Department of Agriculture. National Organic Program. Introduction to Organic Practices. (2015). Retrieved from https://www.ams.usda.gov/publications/content/introduction-organic-practices. Accessed on October 21, 2018.

United States Department of Agriculture. National Organic Program. Do I need to be Certified Organic? (2018). Retrieved from: https://www.ams.usda.gov/services/organiccertification/need-be-certified. Accessed on October 21, 2018.

United States Department of Agriculture. (2015). Coexistence Fact Sheet. Conventional farming. Retrieved from: https://www.usda.gov/sites/default/files/documents/coexistence-conventional-farmingfactsheet.pdf. Accessed on October 8, 2018.

United States Department of Agriculture. (2018). Organic Labeling. Retrieved from: https://www.ams.usda.gov/rules-regulations/organic/labeling. Accessed on October 21, 2018.

United States Department of Agriculture. (2017). Economic Research Service: Organic Market Overview. Retrieved from: https://www.ers.usda.gov/topics/natural-resourcesenvironment/organic-agriculture/organic-market-overview/. Accessed on November 17, 2018.

United States Department of Agriculture. (2017). Economic Research Service: Despite Profit Potential, Organic Field Crop Acreage Remains Low. Retrieved from: https://www.ers.usda.gov/amber-waves/2015/november/despite-profit-potential-organicfield-crop-acreage-remains-low/. Accessed on November 17, 2018.

United States Environmental Protection Agency. (2018). Agriculture: Organic Farming. Retrieved from: https://www.epa.gov/agriculture/agriculture-organic-farming. Accessed on October 21, 2018. Accessed on October 21, 2018.

United States Environmental Protection Agency (2020). Introduction to Pesticide Drift. Retrieved from: https://www.epa.gov/reducing-pesticide-drift/introduction-pesticidedrift. Accessed on February 24, 2020.

U.S. Government Accountability Office. (2020). Farm Programs. Retrieved from: https://www.gao.gov/farm-programs. Accessed on February 16, 2020. 
Vogliano, C., Steiber, A. \& Brown, K. (2015). Linking agriculture, nutrition, and health: The role of the registered dietitian nutritionist. Journal of the Academy of Nutrition and Dietetics, 115(10), 1710-1714.

Welsh, R., \& Rivers, R. Y. (2011). Environmental management strategies in agriculture. Agriculture and Human Values, 28(3), 297-302. 


\section{APPENDIX A}

\section{INSTITUTIONAL REVIEW BOARD MATERIALS}

A-1a: IRB APPROVAL LETTER

A-1b: IRB APPROVAL LETTER FOR AMENDMENT

A-2: CITI CERTIFICATE OF COMPLETION

A-3: INDIVIDUAL INVESTIGATOR AGREEMENT 


\section{Appendix A-1a - IRB Approval Letter}

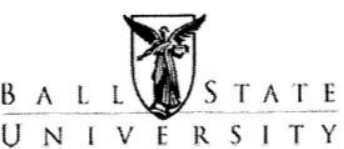

Office of Research Integrity

Institutional Review Board (IRB)

2000 University Avenue

Muncie, IN 47306-0155

Phone: 765-285-5052

Email: orihelp@bsu.edu

DATE:

TO:

FROM:

RE:

TITLE:

SUBMISSION TYPE:

DECISION:

PROJECT STATUS:

DECISION DATE:

REVIEW TYPE:
April 22, 2019

Lindsay Schultz

Ball State University IRB

IRB protocol \# 1398343-1

An exploration of the environmental, nutrition, and health-related attitudes and beliefs that influenced farmers in Indiana and Ohio to choose their farming operation method.

New Project

APPROVED

EXEMPT

April 22, 2019

Exempt Review

The designated reviewer for the Institutional Review Board (IRB) reviewed your protocol and determined the procedures you have proposed are appropriate for exemption under the federal regulations. As such, there will be no further review of your protocol, and you are cleared to proceed with the procedures outlined in your protocol. As an exempt study, there is no requirement for continuing review. Your protocol will remain on file with the IRB as a matter of record. All research under this protocol must be conducted in accordance with the approved submission and in accordance with the principles of the Belmont Report.

\section{Exempt Categories:}

\begin{tabular}{|l|l|}
\hline & $\begin{array}{l}\text { Category 1: Research conducted in established or commonly accepted educational settings, } \\
\text { that specifically involves normal educations practices that are not likely to adversely impact } \\
\text { students' opportunity to learn required educational content or the assessment of educators } \\
\text { who provide instruction. This includes most research on regular and special education } \\
\text { instructional strategies, and research on the effectiveness of or the comparison among } \\
\text { instructional techniques, curricula, or classroom management methods. }\end{array}$ \\
\hline $\mathrm{X}$ & $\begin{array}{l}\text { Category 2: Research that only includes interactions involving educational test (cognitive, } \\
\text { diagnostic, aptitude, achievement), survey procedures, interview procedures, or observation } \\
\text { of public behavior (including visual or auditory recording) if at least one of the following } \\
\text { criteria is met: (i) The information obtained is recorded by the investigator in such a manner }\end{array}$ \\
\hline
\end{tabular}

$$
-1-
$$




\begin{tabular}{|c|}
\hline $\begin{array}{l}\text { that the identity of the human subjects cannot readily be ascertained, directly or through } \\
\text { identifiers linked to the subjects; (ii) Any disclosure of the human subjects' responses outside } \\
\text { the research would not reasonably place the subjects at risk of criminal or civil liability or be } \\
\text { damaging to the subjects' financial standing, employability, educational advancement, or } \\
\text { reputation; or (iii) The information obtained is recorded by the investigator in such a manner } \\
\text { that the identity of the humans subjects can readily be ascertained, directly or through } \\
\text { identifiers linked to the subjects, and an IRB conducts a limited IRB review to make the } \\
\text { determination required by } 46.111(\mathrm{a})(7) \text {. }\end{array}$ \\
\hline $\begin{array}{l}\text { Category 3: Research involving benign behavioral interventions in conjunction with the } \\
\text { collection of information from an adult subject through verbal or written responses (including } \\
\text { data entry) or audiovisual recording if the subject prospectively agrees to the intervention } \\
\text { and information collection and at least one of the following criteria is met: (A) The information } \\
\text { obtained is recorded by the investigator in such a manner that the identity of human subjects } \\
\text { cannot be readily ascertained, directly or through identifiers linked to the subjects; (B) Any } \\
\text { disclosure of the human subjects' responses outside the research would not reasonably } \\
\text { place the subjects at risk of criminal or civil liability or be damaging to the subjects' financial } \\
\text { standing, employability, educational advancement, or reputation; or (C) The information } \\
\text { obtained is recorded by the investigator in such a manner that the identity of the human } \\
\text { subjects can be readily ascertained, directly or through identifiers linked to the subjects, and } \\
\text { an IRB conducts a limited IRB review to make the determination required by } 46.111(\mathrm{a})(7) \text {. }\end{array}$ \\
\hline Category 4: Secondary research for which consent is not required. \\
\hline $\begin{array}{l}\text { Category 5: Research and demonstration projects that are conducted or supported by a } \\
\text { Federal department or agency, or otherwise subject to the approval of department or agency } \\
\text { heads, and that are designed to study, evaluate, improve, or otherwise examine public benefit } \\
\text { or service programs, including procedures for obtaining benefits or services under those } \\
\text { programs, possible changes in or alternatives to those programs or procedures, or possible } \\
\text { changes in methods or levels of payment for benefits or services under those programs. }\end{array}$ \\
\hline $\begin{array}{l}\text { Category 6: Taste and food quality evaluation and consumer acceptance studies, (i) if } \\
\text { wholesome foods without additives are consumed or (ii) if a food is consumed that contains a } \\
\text { food ingredient at or below the level found to be safe, by the Food and Drug Administration or } \\
\text { approved by the Environmental Protection Agency or the Food Safety and Inspection Service } \\
\text { of the U.S. Department of Agriculture. }\end{array}$ \\
\hline $\begin{array}{l}\text { Category 7: Storage or maintenance for secondary research for which broad consent } \\
\text { is required: Storage or maintenance of identifiable private information or identifiable } \\
\text { biospecimens for potential secondary research use if an IRB conducts a limited IRB review } \\
\text { and makes the determinations required by } 46.111(a)(8) \text {. }\end{array}$ \\
\hline $\begin{array}{l}\text { Category 8: Secondary research for which broad consent is required: Research involving } \\
\text { the use of identifiable private information or identifiable biospecimens for secondary research } \\
\text { use, if the following criteria are met: (1)Broad consent for the storage, maintenance, and } \\
\text { secondary research use of the identifiable private information or identifiable biospecimens } \\
\text { was obtained in accordance with } \S 46.116(a)(1) \text { through }(4),(a)(6) \text {, and (d); ( } 2) \text { Documentation } \\
\text { of informed consent or waiver of documentation of consent was obtained in accordance with } \\
\S 46.117 ; \text { and (3) An IRB conducts a limited IRB review and makes the determination required } \\
\text { by } \S 46.111(a)(7) \text { and makes the determination that the research to be conducted is within } \\
\text { the scope of the broad consent referenced in paragraph (d)(8)(i) of this section; and (iv) The } \\
\text { investigator does not include returning individual research results to participants as part of the } \\
\text { study plan. Note: This provision does not prevent an investigator from abiding by any legal } \\
\text { requirements to return individual research results. }\end{array}$ \\
\hline
\end{tabular}

\section{Ball State Specific Exempt Categories}

Category 9: Research involving publicly observable online behavior. Any online behavior that requires a person's permission to access is considered private and does not fall under 


\begin{tabular}{|l|l|}
\hline & $\begin{array}{l}\text { this category. Information that cannot be accessed by the general population would also be } \\
\text { considered private. }\end{array}$ \\
\hline $\begin{array}{l}\text { Category 10: Research involving BSU students who are under } 18 \text { but have legal authority } \\
\text { over their FERPA protected information. Only studies that fall into another exempt category } \\
\text { except for sampling from BSU students who are under } 18 \text { can be considered exempt in this } \\
\text { category. }\end{array}$ \\
\hline
\end{tabular}

While your project does not require continuing review, it is the responsibility of the P.I. (and, if applicable, faculty supervisor) to inform the IRB if the procedures presented in this protocol are to be modified or if problems related to human research participants arise in connection with this project. Any procedural modifications must be evaluated by the IRB before being implemented, as some modifications may change the review status of this project. Please contact Grace Yoder at (765) 285-5034 or gmyoder@bsu.edu if you are unsure whether your proposed modification requires review or have any questions. Proposed modifications should be addressed in writing and submitted electronically to the IRBNet as a "Modification/Amendment" for review. Please reference your IRB protocol number 1398343-1 in any communication to the IRB regarding this project.

In the case of an adverse event and/or unanticipated problem, you will need to submit written documentation of the event to IRBNet under this protocol number and you will need to directly notify the Office of Research Integrity (http://www.bsu.edu/irb) within 5 business days. If you have questions, please contact Grace Yoder at (765) 285-5034 or gmyoder@bsu.edu.

Reminder: Even though your study is exempt from the relevant federal regulations of the Common Rule (45 CFR 46, subpart A), Ball State has elected to hold you accountable to these regulations to encourage best research practices. You and your research team are not exempt from ethical research practices and should therefore employ all protections for your participants and their data which are appropriate to your project. 


\section{Appendix A-1b - IRB Approval Letter for Amendment}

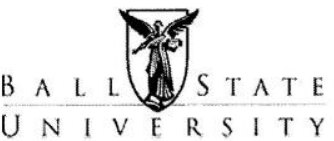

Office of Research Integrity

Institutional Review Board (IRB)

2000 University Avenue

Muncie, IN 47306-0155

Phone: 765-285-5052

E-mail: orihelp@bsu.edu

DATE:

TO:

FROM:

RE:

TITLE:

SUBMISSION TYPE:

ORIGINAL APPROVAL

DATE:

ACTION:

PROJECT STATUS:

DECISION DATE:

EXPIRATION DATE:

REVIEW TYPE:
May 6, 2019

Lindsay Schultz

Ball State University IRB

IRB protocol \# 1398343-2

An exploration of the environmental, nutrition, and health-related attitudes and beliefs that influenced farmers in Indiana and Ohio to choose their farming operation method

Amendment/Modification

April 22, 2019

APPROVED

EXEMPT

May 6, 2019

Exempt Review

The Institutional Review Board (IRB) has reviewed your Amendment/Modification for An exploration of the environmental, nutrition, and health-related attitudes and beliefs that influenced farmers in Indiana and Ohio to choose their farming operation method.. Your project was deemed MINIMAL RISK and approved on April 22, 2019. The changes you requested were reviewed at the Exempt Review level and were approved on May 6, 2019. Your project has been reviewed at the Exempt level per category 2.

As a reminder, it is the responsibility of the P.I. and/or faculty sponsor to inform the IRB in a timely manner:

- when the project is completed,

- if the project is to be continued beyond the approved end date (if applicable),

- if the project is to be modified further,

- if the project encounters problems, or

- if the project is discontinued. 
Any of the above notifications should be addressed in writing and submitted electronically to IRBNet (www.irbnet.org). Please reference the IRB protocol number 1398343-2 in any communication to the IRB regarding this project. Be sure to allow sufficient time for review and approval of requests for modification or continuation. If you have questions, please contact Grace Yoder at (765) 285-5034 or gmyoder@bsu.edu.

In the case of an adverse event and/or unanticipated problem, you will need to submit written documentation of the event to IRBNet under this protocol number and you will need to directly notify the Office of Research Integrity (http://www.bsu.edu/irb) within 5 business days. In case of any emergency do not wait 5 days to submit the report, contact the office at once. If you have questions, please contact Grace Yoder at (765) 285-5034 or gmyoder@bsu.edu.

Please note that all research records must be retained for a minimum of three years after the completion of the project or as required under Federal and/or State regulations (ex. HIPAA, FERPA, etc.). Additional requirements may apply. 
Appendix A-2 - CITI Certificate of Completion
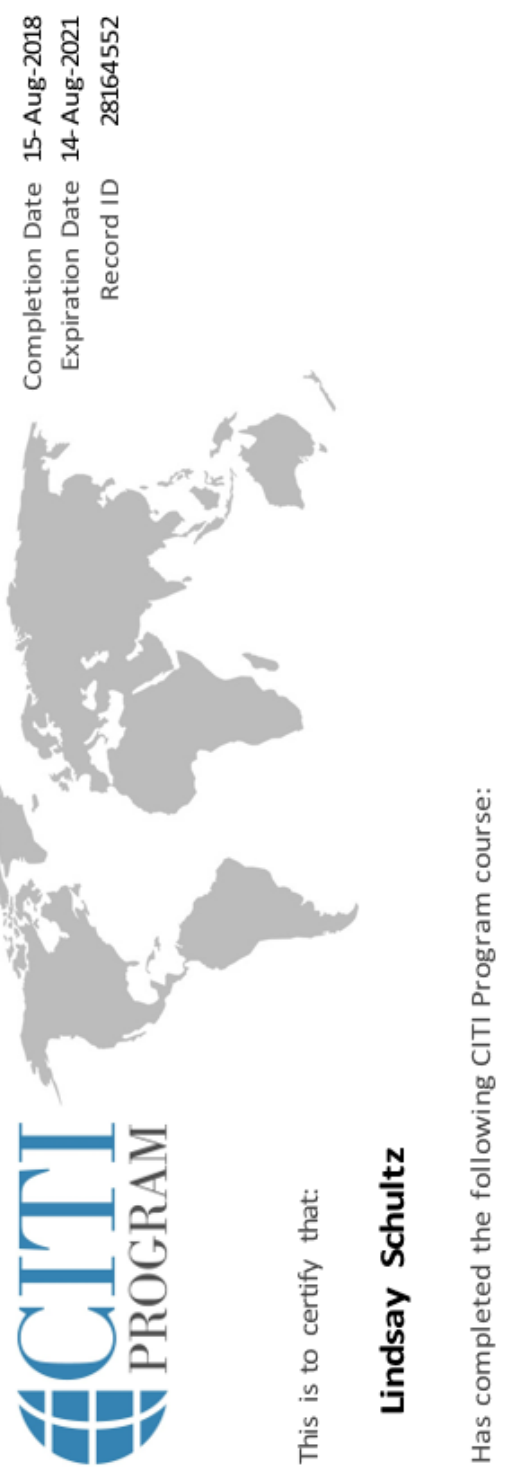

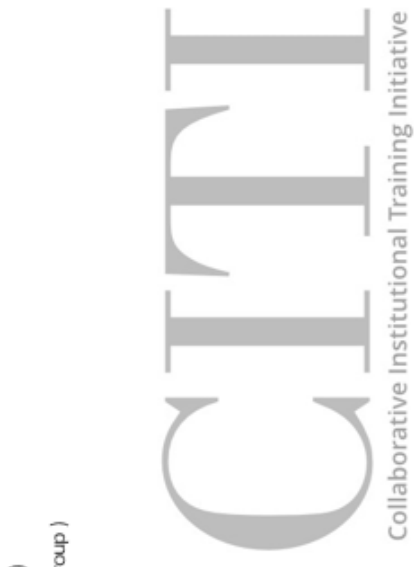




\section{Appendix A-3: Individual Investigator Agreement}

Office of Research Integrity

Institutional Review Board (IRB)

2000 University Avenue

Muncie, IN 47306-0155

Phone: 765-285-5070

http://cms.bsu.edu/about/administrativeoffices/researchintegrity

\section{INDIVIDUAL INVESTIGATOR AGREEMENT (IIA)}

Name of Institution with the Federalwide Assurance (FWA): Ball State University

Applicable FWA \#: FWA00000797

Individual Investigator Name: Eric Schultz

Protocol (IRBNet) Number:

\section{3-1}

Federally Funded: $C$ Yes

6 No

This agreement is to only be used in cases where the named individual is not covered by any other registered Institutional Review Board (IRB) or Federalwide Assurance (FWA). Terms of this Agreement are not to be altered without the expressed written permission of the BSU Director, Office of Research Integrity (ORI) or their designee.

1. The above-named Individual Investigator (hence forth Investigator) has reviewed:

a. The Belmont Report: Ethical Principles and Guidelines for the Protection of Human Subjects of Research;

b. The U.S. Department of Health and Human Services (HHS) regulations for the protection of human subjects at 45 CFR part 46 (aka The Common Rule);

c. The FWA and applicable Terms of the FWA for the institution referenced above; and

d. The relevant institutional policies and procedures for the protection of human subjects.

2. The Investigator understands and hereby accepts the responsibility to comply with the standards and requirements stipulated in the above documents and to protect the rights and welfare of human subjects involved in research conducted under this Agreement.

3. The Investigator will comply with all other applicable federal, international, state, and local laws, regulations, and policies that may provide additional protection for human subjects participating in research conducted under this agreement. The Investigator will abide by all determinations of the Institutional Review Board (IRB) designated under the above FWA and will accept the final authority and decisions of the IRB, including but not limited to directives to terminate participation in designated research activities.

4. The Investigator will complete any educational training required by the Institution and/or the IRB prior to initiating research covered under this Agreement. The Investigator will also maintain any require licenses, certifications, professional credentials and so forth that may be required by their profession and that are involved in the research covered under this agreement.

5. The Investigator will report promptly to the IRB any proposed changes in the research conducted under this Agreement. The investigator will not initiate changes in the research without prior IRB review and approval, except where necessary to eliminate apparent immediate hazards to subjects.

6. The Investigator will report immediately to the IRB any unanticipated problems involving risks to subjects or others in research covered under this Agreement.

7. The Investigator, when responsible for enrolling subjects, will obtain, document, and maintain records of informed consent for each such subject or each subject's legally authorized representative as required under HHS regulations at 45 CFR part 46 and stipulated by the IRB.

8. The Investigator acknowledges and agrees to cooperate in the IRB's responsibility for initial and continuing review, record keeping, reporting, and certification for the research referenced above. The Investigator will provide all information requested by the IRB in a timely fashion.

9. The Investigator will not enroll subjects in research under this Agreement prior to its review and approval by the IRB.

10. Emergency medical care may be delivered without IRB review and approval to the extent permitted under applicable federal regulations and state law. 
11. This Agreement does not preclude the Investigator from taking part in research not covered by this Agreement.

12. The Investigator acknowledges that he/she is primarily responsible for safeguarding the rights and welfare of each research subject, and that the subject's rights and welfare must take precedence over the goals and requirements of the research.

(Please read and check the box)

Х I state that I am not covered by any other registered Institutional Review Board (IRB) or Federalwide Assurance (FWA) and that I agree to all the terms listed above:

\section{INVESTIGATOR:}

\begin{tabular}{|l|l|l|l|l|}
\hline Schultz & Eric \\
\hline Last Name & First Name \\
\hline 315 W. Herr Street & CSA \\
\hline Address & Country \\
\hline Zip Code & \\
\hline
\end{tabular}

Investigator Signature (Print/Sign \& Date)

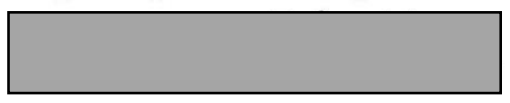


Office of Research Integrity

Institutional Review Board (IRB)

2000 University Avenue

Muncie, IN 47306-0155

Phone: 765-285-5070

http://cms.bsu.edu/about/administrativeoffices/researchintegrity

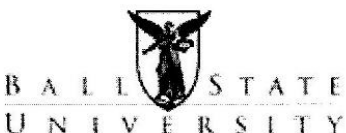

\section{INDIVIDUAL INVESTIGATOR AGREEMENT (IIA)}

Name of Institution with the Federalwide Assurance (FWA): Ball State University

Applicable FWA \#: FWA00000797

Individual Investigator Name: Cindy Ragon

Protocol (IRBNet) Number:

\section{3-1}

Federally Funded: $C$ Yes

- No

This agreement is to only be used in cases where the named individual is not covered by any other registered Institutional Review Board (IRB) or Federalwide Assurance (FWA). Terms of this Agreement are not to be altered without the expressed written permission of the BSU Director, Office of Research Integrity (ORI) or their designee.

1. The above-named Individual Investigator (hence forth Investigator) has reviewed:

a. The Belmont Report: Ethical Principles and Guidelines for the Protection of Human Subjects of Research;

b. The U.S. Department of Health and Human Services (HHS) regulations for the protection of human subjects at 45 CFR part 46 (aka The Common Rule);

c. The FWA and applicable Terms of the FWA for the institution referenced above; and

d. The relevant institutional policies and procedures for the protection of human subjects.

2. The Investigator understands and hereby accepts the responsibility to comply with the standards and requirements stipulated in the above documents and to protect the rights and welfare of human subjects involved in research conducted under this Agreement.

3. The Investigator will comply with all other applicable federal, international, state, and local laws, regulations, and policies that may provide additional protection for human subjects participating in research conducted under this agreement. The Investigator will abide by all determinations of the Institutional Review Board (IRB) designated under the above FWA and will accept the final authority and decisions of the IRB, including but not limited to directives to terminate participation in designated research activities.

4. The Investigator will complete any educational training required by the Institution and/or the IRB prior to initiating research covered under this Agreement. The Investigator will also maintain any require licenses, certifications, professional credentials and so forth that may be required by their profession and that are involved in the research covered under this agreement.

5. The Investigator will report promptly to the IRB any proposed changes in the research conducted under this Agreement. The investigator will not initiate changes in the research without prior IRB review and approval, except where necessary to eliminate apparent immediate hazards to subjects.

6. The Investigator will report immediately to the IRB any unanticipated problems involving risks to subjects or others in research covered under this Agreement.

7. The Investigator, when responsible for enrolling subjects, will obtain, document, and maintain records of informed consent for each such subject or each subject's legally authorized representative as required under HHS regulations at 45 CFR part 46 and stipulated by the IRB.

8. The Investigator acknowledges and agrees to cooperate in the IRB's responsibility for initial and continuing review, record keeping, reporting, and certification for the research referenced above. The Investigator will provide all information requested by the IRB in a timely fashion.

9. The Investigator will not enroll subjects in research under this Agreement prior to its review and approval by the IRB.

10. Emergency medical care may be delivered without IRB review and approval to the extent permitted under applicable federal regulations and state law. 
11. This Agreement does not preclude the Investigator from taking part in research not covered by this Agreement.

12. The Investigator acknowledges that he/she is primarily responsible for safeguarding the rights and welfare of each research subject, and that the subject's rights and welfare must take precedence over the goals and requirements of the research.

(Please read and check the box)

$\bigotimes$ I state that I am not covered by any other registered Institutional Review Board (IRB) or Federalwide Assurance (FWA) and that I agree to all the terms listed above:

\section{INVESTIGATOR:}

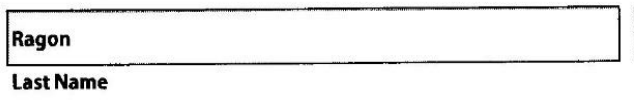

315 W. Herr Street

Address

45322

Zip Code

USA

USA

\begin{tabular}{l}
\hline Cindy \\
First Name \\
\hline
\end{tabular}

City

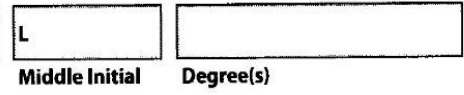

Middle Initial Degree(s)

\begin{tabular}{|l|l|}
\hline Cip Code & Country \\
\hline Investigator Signature (Print/Sign \& Date)
\end{tabular} 


\section{APPENDIX B}

\section{SURVEY INSTRUMENTS}

B-1: INVITATION TO PARTICPATE SCRIPT

B-2: INTERVIEW QUESTIONS

B-3: DEMOGRAPHIC QUESTIONNAIRE 


\section{Appendix B-1: Invitation to Participate Script}

Hello. My name is Lindsay Schultz. I am a graduate student at Ball State University. I am working on a thesis project to obtain my Master's Degree in the area of nutrition and dietetics. I would like to kindly invite you to participate in my thesis project exploring the attitudes and factors that motivate farmers from Indiana and Ohio to operate either a certified organic, a non-certified organic, or a conventional farm. By participating in this study, you would be assisting me in completing requirements for my degree. You would also be aiding in gathering research in the fields of nutrition, agriculture and the environment. If you would like to participate, we will simply need to set up a one-time meeting. At this meeting, we would complete a 30-45-minute interview which will be audio recorded. I would be more than happy to come to your farm for the interview. 
Appendix B-2: Interview Questions

Thank you for taking time out of your day, and allowing me the opportunity to conduct this interview with you. By participating in this study, you will aide me in the completion of my thesis project required to earn a Master's degree in Nutrition and Dietetics. The results from this study will provide great insight into the farming community. The results could potentially provide evidence about how working with registered dietitians could impact the farmers' business and also impact the health of the community. The interview will last about 30-45 minutes. I will be asking you questions regarding your farming methods and your thoughts about your business decisions. I hope to gain a better understanding of farmers' perspectives and decisions regarding farming practices.

1. What made you decide to go into farming?

2. Why did you decide to grow the crops you do?

3. Why did you decide to run a certified organic, non-certified organic or conventional farm?

4. Can you share with me the benefits of your farming method?

5. Can you share with me about the challenges in using your method of farming?

6. How have your farming operations changed over time?

7. What are the most important resources of your farm?

a. How do you manage these resources?

8. How do you think your farming methods affect the environment?

9. Please share with me any policies or rules, both state and nationally, that may affect the way you run your farm.

a. How would a policy or rule change affect the way you run your farm? 
b. If you had to rank policy change in your decision making relative to other decisions, on a scale of 1-5 (with 1 little impact and 5 extreme impact), what impact does policy have on your decisions?

10. How do you sell and market your products?

a. Prompt if needed: Direct to consumer, retail or wholesale, institutions?

11. How does the type of market or people you sell to influence your decisions on how you run your farm?

12. How does your role as a farmer affect the health of others?

13. The USDA Dietary Guidelines recommends that Americans consume $2 \frac{1 / 2}{2}$ cups of vegetables and 2 cups of fruit each day. What are your thoughts on that recommendation?

a. Do you believe people in (Ohio if farmer resides in $\mathrm{OH}$, or Indiana if farmer resides in IN) follow these recommendations? Why/why not?

b. How can a farmer influence consumers to meet this recommendation?

14. Registered dietitians are experts in the use of food and nutrition to promote health and help manage diseases. Dietitians can play a role in the government by participating in policy discussions related to the topics on health that includes the Farm Bill, for example. How could working with a registered dietitian (RDN) help with your farming business?

a. How could working with an RDN affect consumer awareness about your products? (prompt, if not already stated)

b. How could working with an RDN affect the health of your consumers? (prompt, if not already stated)

15. What advice do you have for dietitians and the public who want to better understand how food is produced?

16. What are your future plans for your farm?

After the interview is completed, the researcher will ask the interviewee if there are other farmers that they may recommend to participate in this study as well. Contact information for the farmers will be obtained from the interviewee if there are recommendations. 
Appendix B-3: Demographic Questionnaire

\section{Demographic Questions}

Interview \#

What is your age?

What is your gender? (circle one) Male Female

What is your education level? (check highest level)

High School

2-year college

4-year college

Advanced degree

Other

In what state(s) do you farm? (circle all that apply) Ohio Indiana

How many years have you been operating your farm?

What type of products do you grow and sell? (check all that apply)

$\square$ Vegetables

Fruit

Commodity crops

Specialty crops (premium price point produce/crops)

Other

What is your annual gross in sales? (check 2018 sales)

Less than $\$ 25,000$

$\$ 25,000-49,999$

$\$ 50,000-99,000$

$\$ 100,000-249,999$

$\$ 250,000-499,999$

$\$ 500,000-999,999$

More than $\$ 1,000,000$

How many acres do you farm? 
APPENDIX C

LETTER OF CONSENT 
Appendix C: Informed Consent

\section{Study Title}

An exploration of the environmental, nutrition, and health-related attitudes and beliefs that influenced farmers in Indiana and Ohio to choose their farming operation method.

\section{Study Purpose and Rationale}

The purpose of this qualitative study is to explore the attitudes and factors that motivate farmers from Indiana and Ohio to operate either a certified organic, a non-certified organic, or a conventional farm.

\section{Inclusion/Exclusion Criteria}

To be eligible to participate in this study, you must be an owner and/or operator of a farm in Indiana or Ohio and be over 18 years of age.

\section{Participation Procedures and Duration}

For this study, you will be asked to complete an interview. It will take approximately 30-45 minutes to complete the interview.

\section{Audio or Video Tapes (if applicable)}

With your permission, the interviews will be audio recorded. No names will be used on the audio recordings or transcript.

\section{Data Confidentiality or Anonymity}

All data will be maintained as confidential and no identifying information such as names will appear in any publication or presentation of the data. Each study participant will be assigned a random number as their identification for the researcher. A list of the identification numbers and matching participant names will be kept in a locked filing cabinet by the researcher for up to three years, then destroyed.

\section{Storage of Data}

The data will be entered into a software program and stored on the researcher's passwordprotected computer for up to three years and then deleted. Only members of the research team will have access to the data.

\section{Risks or Discomforts}

The only anticipated risk from participating in this study is that you may not feel comfortable answering some of the questions. You may choose not to answer any question that makes you uncomfortable and you may quit the study at any time.

\section{Benefits}

There are no perceived benefits for participating in this study.

\section{Voluntary Participation}

Your participation in this study is completely voluntary and you are free to withdraw your permission at any time for any reason without penalty or prejudice from the investigator. Please feel free to ask any questions of the investigator before signing this form and at any time during the study. 


\section{IRB Contact Information}

For one's rights as a research subject, you may contact the following: For questions about your rights as a research subject, please contact the Director, Office of Research Integrity, Ball State University, Muncie, IN 47306, (765) 285-5070 or at irb@bsu.edu.

\section{Consent}

I, attitudes and beliefs that influenced farmers in Indiana and Ohio to choose their farming operation method." I have had the study explained to me and my questions have been answered to my satisfaction. I have read the description of this project and give my consent to participate. I understand that I will receive a copy of this informed consent form to keep for future reference.

To the best of my knowledge, I meet the inclusion/exclusion criteria for participation (described on the previous page) in this study.

Participant's Signature

Date

\section{$\underline{\text { Researcher Contact Information }}$}

Principal Investigator:

Faculty Supervisor:

Lindsay N. Schultz, Graduate Student

Dr. Deanna Pucciarelli

Nutrition and Dietetics

Ball State University

Muncie, IN 47306

Nutrition and Dietetics

Telephone: (937) 654-4637

Ball State University

Muncie, IN 47306

Email: Inschultz@bsu.edu

Telephone: (765) 285-4791

Email: dpucciarelli@bsu.edu 